\title{
The drivers of biogeochemistry in beach ecosystems: A cross-shore transect from the dunes to the low-water line
}

\author{
Melanie Beck ${ }^{\mathrm{a}, *}$, Anja Reckhardt ${ }^{\mathrm{a}, *}$, Julia Amelsberg a , Alexander Bartholomä b, Hans-Jürgen Brumsack ${ }^{\mathrm{a}}$, \\ Heribert Cypionka ${ }^{a}$, Thorsten Dittmar ${ }^{a}$, Bert Engelen ${ }^{a}$, Janek Greskowiak ${ }^{c}$, Helmut Hillebrand ${ }^{a}$, \\ Moritz Holtappels ${ }^{\mathrm{d}, 1}$, René Neuholz ${ }^{\mathrm{a}}$, Jürgen Köster ${ }^{\mathrm{a}}$, Marcel M.M. Kuypers ${ }^{\mathrm{d}}$, Gudrun Massmann ${ }^{\mathrm{c}}$, \\ Daniela Meier ${ }^{a}$, Jutta Niggemann ${ }^{a}$, Ronja Paffrath ${ }^{a}$, Katharina Pahnke ${ }^{a}$, Sandra Rovo ${ }^{\text {a }}$, Maren Striebel ${ }^{a}$, \\ Verona Vandieken ${ }^{\mathrm{a}}$, Achim Wehrmann ${ }^{\mathrm{b}}$, Oliver Zielinski ${ }^{\mathrm{a}}$ \\ a Institute for Chemistry and Biology of the Marine Environment (ICBM), Carl von Ossietzky University of Oldenburg, Oldenburg, Germany \\ b Senckenberg am Meer, Wilhelmshaven, Germany \\ c Institute for Biology and Environmental Sciences, Carl von Ossietzky University of Oldenburg, Oldenburg, Germany \\ ${ }^{\mathrm{d}}$ Max Planck Institute for Marine Microbiology, Bremen, Germany
}

\section{A R T I C L E I N F O}

\section{Article history:}

Received 30 September 2016

Received in revised form 22 December 2016

Accepted 6 January 2017

Available online 07 January 2017

\section{Keywords:}

North Sea

Submarine groundwater discharge

Organic matter and nutrient cycling

Microorganisms and phytobenthos

\begin{abstract}
A B S T R A C T
This study addresses key processes in high-energy beach systems using an interdisciplinary approach. We assess spatial variations in subsurface pore water residence times, salinity, organic matter (OM) availability, and redox conditions and their effects on nutrient cycles as well as on microbial community patterns and microphytobenthos growth. At the study site on Spiekeroog Island, southern North Sea, beach hydrology is characterized by the classical zonation with an upper saline plume (USP), a saltwater wedge, and a freshwater discharge tube in between. Sediment and pore water samples were taken along a cross-shore transect from the dunes to the low-water line reaching sediment depths down to $5 \mathrm{~m}$ below sediment surface. Spatial variations in pore water residence time, salinity, and organic matter availability lead to steep redox and nutrient gradients. Vertical and horizontal differences in the microbial community indicate the influence of these gradients and salinity on the community structure. Modeled seawater flux through the USP and freshwater flux through the tube are on average 2.8 and $0.75 \mathrm{~m}^{3}$ per day and meter of shoreline, respectively. Furthermore, ridge sediments at the lower beach discharge seawater at rates of 0.5 and $1.0 \mathrm{~m}^{3}$ per day and meter of shoreline towards the runnel and seaside, respectively. Applying seawater and freshwater fluxes and representative nutrient concentrations for the discharge zones, nutrient fluxes to adjacent nearshore waters are $117 \mathrm{mmol} \mathrm{NH}_{4}^{+}, 55 \mathrm{mmol} \mathrm{PO}_{4}^{3-}$ and $575 \mathrm{mmol} \mathrm{Si}(\mathrm{OH})_{4}$ per day and meter of shoreline. We propose that this nutrient efflux triggers growth of microphytobenthos on sediment surfaces of the discharge zone. A first comparison of nutrient discharge rates of the beach site with a nearby sandy backbarrier tidal flat margin indicates that the beach system might be of less importance in supplying recycled nutrients to nearshore waters than the backbarrier tidal flat area.
\end{abstract}

@ 2017 Elsevier B.V. All rights reserved.

\section{Introduction}

Sandy beaches as coastal ecosystems provide important ecosystem services, such as reduction of storm impacts, nutrient cycling, water purification, nursery and feeding-breeding habitats (Nel et al., 2014 and references therein). However, beach ecosystems are vulnerable and may be affected, for example, by erosion caused by climate-induced sea level rise (Hinkel et al., 2013) or increased nitrogen availability

\footnotetext{
* Corresponding authors.

E-mail addresses: m.beck@icbm.de (M. Beck), anja.reckhardt@uni-oldenburg.de (A. Reckhardt).

Present address: Alfred Wegener Institute, Bremerhaven, Germany.
}

due to human activities (Ibánhez and Rocha, 2014). To preserve the ecosystem services and to assess the vulnerability of beach ecosystems, it is a prerequisite to develop a detailed understanding of the biogeochemical processes and dynamics in these systems. However, there is a lack of understanding compared to other coastal systems such as estuaries, coral reefs, and mangroves (Nel et al., 2014).

Sandy beach systems are an important part of the global land-sea interface because they make up two-thirds of the world's ice free coastline (McLachlan and Brown, 2006). Several studies show that sandy beach sediments exert a major effect on coastal carbon, nutrient, and trace element cycling (Anschutz et al., 2016, 2009; Charbonnier et al., 2013; Heiss and Michael, 2014; Rodellas et al., 2014; Santoro, 2010; Santos et al., 2008). Sandy sediments are characterized by a high permeability, 
which permits advective pore water flow besides diffusion (Huettel et al., 1998; Riedel et al., 2010). Consequently, seawater infiltration continuously supplies oxygen and fresh organic matter to the sediment leading to high levels of organic matter (OM) degradation (Huettel et al., 2014) and nutrient cycling (Gao et al., 2012; Marchant et al., 2014). When remineralization products are discharged into the coastal zone via submarine groundwater discharge (SGD), they can stimulate primary production and may even cause harmful algae blooms and eutrophication (Paerl, 1997). The phenomenon of SGD is observed worldwide (Moore, 1996) and the global magnitude of fresh and saline SGD is estimated to be larger than riverine fluxes to the ocean (Kwon et al., 2014; Moore et al., 2008). However, the contribution of beach systems to global SGD budgets and consequently the global importance of beaches for the cycling of nutrients, carbon species, and trace elements need to be studied in more detail.

Beach ecosystems represent major transition zones (land-sea, freshwater-saltwater, oxic-anoxic). Biogeochemical processes are controlled by groundwater flow pathways and residence times, which depend on physical factors such as tidal amplitude, wave height, seasonal changes in water table elevation (Anwar et al., 2014; Gibbes et al., 2008; Michael et al., 2005; Robinson et al., 2007b, 2014), beach morphology, and sediment permeability (Bakhtyar et al., 2011; Butt et al., 2001). Additionally, chemical gradients related to OM flux and redox changes influence the ecosystem (Charette and Sholkovitz, 2006; Loveless and Oldham, 2010; McAllister et al., 2015; Santos et al., 2008). Therefore, the biota in these ecosystems have to cope with strong chemical and physical constraints (Harris et al., 2011; Hubas et al., 2007b; Rodil and Lastra, 2004). Nevertheless, it was shown that despite these steep gradients, beach systems exhibit a high microbial activity (Forehead et al., 2013) and that the microbial community can modulate its growth efficiency when exposed to environmental stress (Hubas et al., 2007a).

Although beach ecosystems might be of importance for global biogeochemical cycles, significant disciplinary and interdisciplinary gaps in understanding beach ecosystem functioning remain because most studies were uni-disciplinary and focused either on ecology, physical beach environment, management, or biology (Dugan et al., 2010; Nel et al., 2014). Therefore, we conducted a study that combines the disciplines sedimentology, hydrology, biogeochemistry, microbiology, and ecology. We assessed the effects of spatial variations in subsurface pore water residence times, salinity, OM availability, and redox conditions on $\mathrm{OM}$ and nutrient cycling as well as on microbial community patterns and microphytobenthos growth. Furthermore, we tested the hypothesis that exposed beach systems facing the open North Sea are of greater importance for nutrient recycling and efflux than sandy backbarrier tidal flat sediments.

\section{Material and methods}

\subsection{Study area and sampling strategy}

Spiekeroog forms part of the barrier island chain in front of the North-west German coastline (Fig. 1). The island has a length of $9.8 \mathrm{~km}$ and a maximum width of $2 \mathrm{~km}$. Barrier islands like Spiekeroog are typically characterized by a freshwater lens, which develops as precipitation continuously infiltrates into the often highly permeable sediments and overlies the saltwater (Röper et al., 2013). In addition to wind and wave driven processes, the island's beaches are affected by semidiurnal tides with a mean tidal range of $2.7 \mathrm{~m}$ (mesotidal). The offshore wave spectrum varies from $0.5-2 \mathrm{~m}$ at fair weather up to $11 \mathrm{~m}$ during storm conditions (Dobrynin et al., 2010). The beach slope of $2.3^{\circ}$ from the back- to the foreshore, measured during the sampling campaign in May 2014, reflects the transitional stage of beach morphology from the dissipative winter situation to the reflective summer situation, classified after Short and Woodroffe (2009) (Fig. 2). A winter berm is well developed directly at the transition

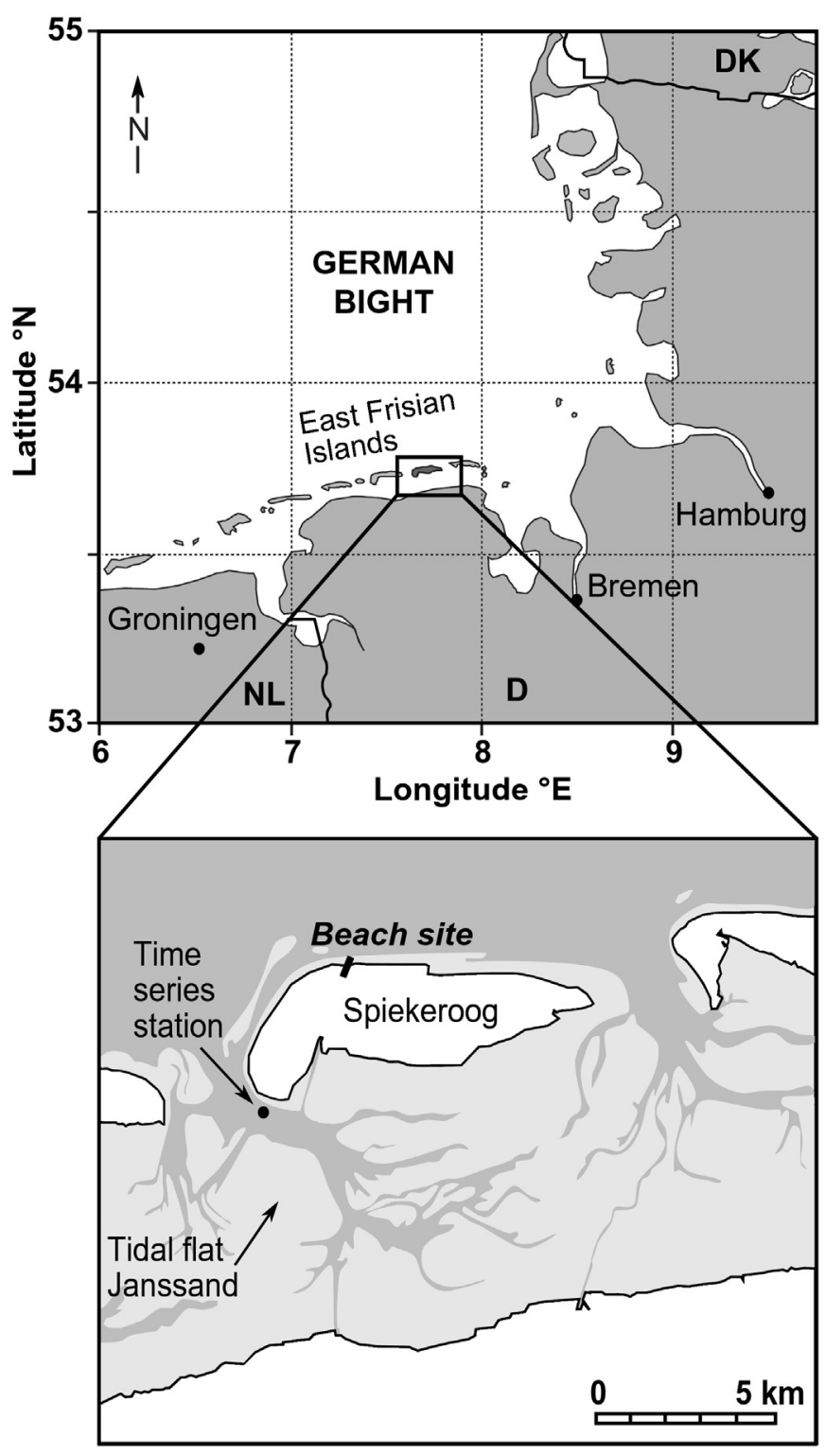

Fig. 1. The study area is located in the southern North Sea where a chain of barrier islands divided by tidal inlets, separates the backbarrier tidal flats from the open North Sea. Sampling was conducted on Spiekeroog Island, which forms part of the East Frisian Barrier Island chain at the German North Sea coast. The studied beach site (black line) at the northern side of this barrier island is facing the open North Sea.

from the backshore to the foreshore. The foreshore is dissected by a ridge and runnel system, which is oriented slightly shore-oblique. During falling tide, the runnels drain the emerged parts of the beach towards the East.

In line with the gradients in hydrodynamic energy and topography, we have chosen a land-sea transect on the exposed seaward-facing side of Spiekeroog Island for the investigations (Fig. 1). During a joint sampling campaign in May 2014, sediment, pore water, and water column samples were collected. The main beach transect consisted of five sites extending from close the dunes (site 0 and 1 , both behind a backshore berm), to the high tide line (site 2 ), to a ridge (site 3 ), and finally to the low-water line (site 4). Sedimentological studies extended to the shoreface as well including the two subtidal sites 5 and 6 (Fig. 2). Furthermore, phytobenthos samples were collected along three transects (with $50 \mathrm{~m}$ distance in between), stretching from the high to the low-water line (Phytobenthos 1-11; Fig. 2). Hydrological data were recorded close to sites 0,2 , and 3 (GWM 0, 2, 3; Fig. 2). 


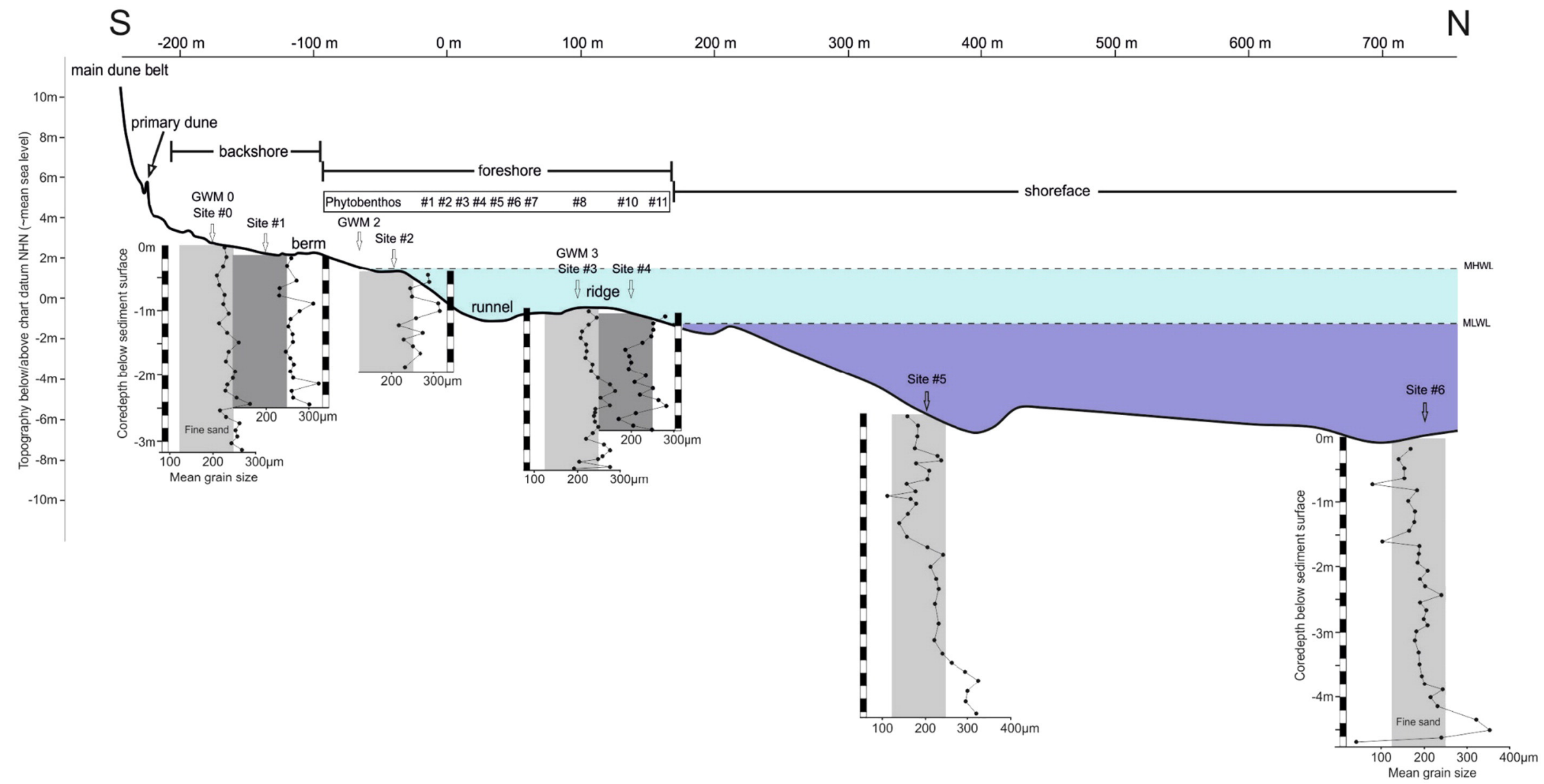

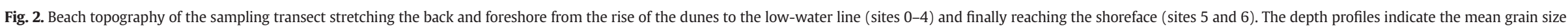

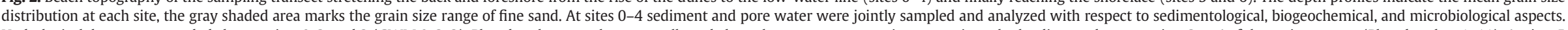

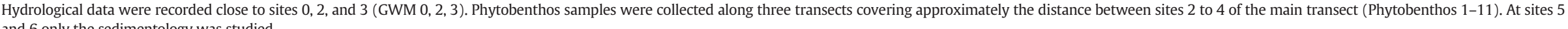
and 6 only the sedimentology was studied. 


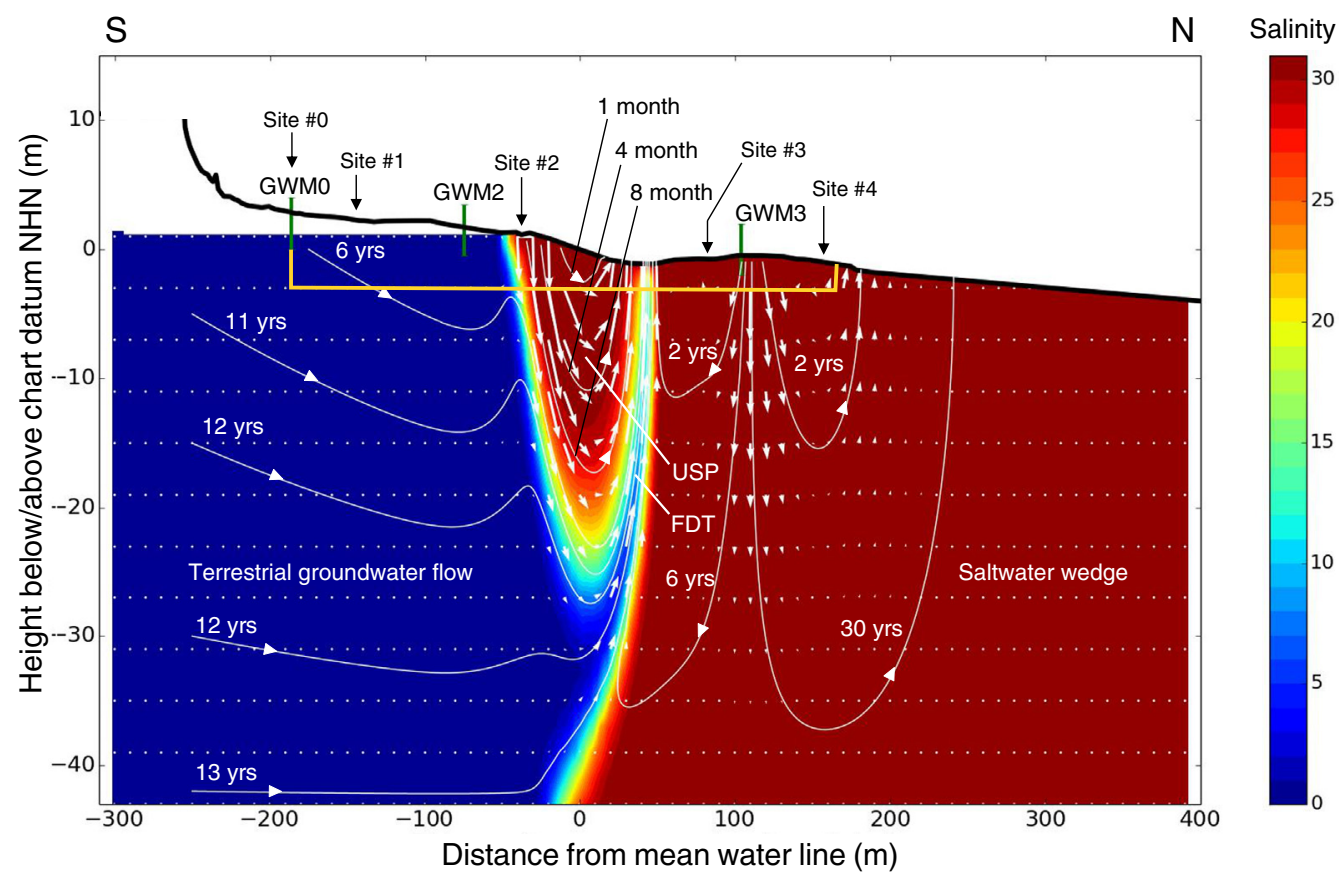

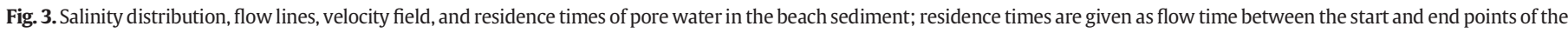

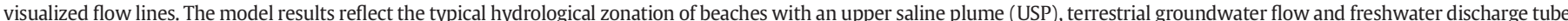

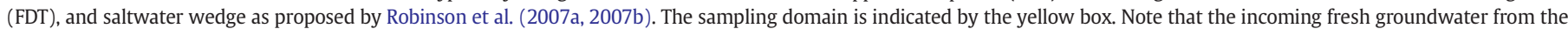

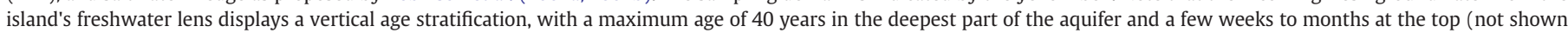
here). (For interpretation of the references to color in this figure legend, the reader is referred to the web version of this article.)

\subsection{Sample and data collection}

\subsubsection{Measurement of beach topography}

The beach topography and study sites were mapped with a Trimble 5800 GPS using a data correction service, which minimizes the accuracy error of the geographic position (WGS 84) to 12-19 mm both vertically and horizontally.

\subsubsection{Hydraulic investigations}

Three groundwater monitoring wells (GWM) were installed along the transect. (Figs. 2, 3). At these wells, groundwater level measurements were continuously recorded with pressure transducers (Schlumberger Mini-Diver) for a duration of 3 days. All measured groundwater levels were corrected for the groundwater specific density and air pressure.

\subsubsection{Sediment sampling}

Sediment cores were taken at seven sites (five at the backshore/foreshore and two offshore ones; Fig. 2). The offshore cores at sites 5 and 6 were taken on board the research vessel "Senckenberg" using an electric underwater vibrocorer. Onshore cores were taken by vibrocoring as described by Wilms et al. (2006). Sediment was recovered in aluminum tubes (onshore, $8 \mathrm{~cm}$ inner diameter) or PVC-liners (offshore, $10 \mathrm{~cm}$ inner diameter). For biogeochemical and molecular analyses, sediment cores were transported to the lab and immediately processed. Cores were cut transversely at respective depth intervals to take subcores from the innermost parts of freshly opened sides by using sterile syringes with cutoff tips. For DNA extraction sediment samples were stored at $-20^{\circ} \mathrm{C}$, and for total cell counts sediment was fixed in formaldehyde. For sedimentological analyses cores were cut lengthwise.

For analyzing particulate nutrient and chlorophyll $a$ concentrations of the benthic microalgae community, sediment corers made of hard plastic material with a length of $20 \mathrm{~cm}$ and a diameter of $1.9 \mathrm{~cm}$ were used. All corers were filled by putting $3 \mathrm{~cm}$ of each corer into the sediment and closing them with rubber stoppers at both sides.

\subsubsection{Water column sampling}

Seawater samples for dissolved organic matter (DOM) and rare earth element (REE) analyses were taken during low and high tide at $\sim 0.5 \mathrm{~m}$ water depth by submerging 21 polycarbonate bottles (Nalgene, acid-rinsed). Samples were processed as described in the subsequent paragraph. Filtered REE samples were filled into acid-cleaned $500 \mathrm{ml}$ high-density polyethylen bottles and acidified with ultra-clean $\mathrm{HCl}$ to a $\mathrm{pH}$ of $\sim 2$.

\subsubsection{Pore water sampling}

Pore water sampling down to $2 \mathrm{~m}$ below sediment surface (mbss) was done using stainless steel push point samplers as described in Reckhardt et al. (2015). Sediment depths exceeding 2 mbss were sampled by elongating a stainless steel tip stepwise with $90 \mathrm{~cm}$ long steel extension rods (outer diameter $15 \mathrm{~mm}$ ), which were pushed into the ground by percussion drilling (Charette and Allen, 2006). Pore water samples were collected through a $6 \mathrm{~m}$ long Teflon tube (inner diameter $5 \mathrm{~mm}$ ) using a vacuum hand pump. Samples from the island's freshwater lens were obtained as described in Röper et al. (2012).

Aliquots for metal (Mn, Fe), total sulfur, silica and phosphate analyses via ICP-OES and samples for photometric nutrient analyses $\left(\mathrm{NO}_{\mathrm{x}}^{-}\right.$, $\mathrm{NO}_{2}^{-}, \mathrm{NH}_{4}^{+}$, total alkalinity) were treated as specified in Reckhardt et al. (2015). Aliquots for REE were filtered through AcroPak500 cartridges with 0.8/0.2 $\mu \mathrm{m}$ Supor filter membrane and acidified with ultrapure $6 \mathrm{M}$ $\mathrm{HCl}$ to a $\mathrm{pH}$ of $\sim 2$. Metal and nutrient samples were stored dark and at $4{ }^{\circ} \mathrm{C}$ until analysis. For hydrogen sulfide analysis, $1 \mathrm{ml}$ of sample was pipetted immediately into an Eppendorf vial, which contained $1 \mathrm{ml} \mathrm{ZnCl} 2$ solution (2\%). Salinity was determined directly in the field with a Multi 3430 (WTW) conductivity sensor. Samples for pore water $(500 \mathrm{ml})$ and seawater (2 L) DOM analysis were immediately filtered through a sequence of pre-combusted $\left(400{ }^{\circ} \mathrm{C}, 4 \mathrm{~h}\right.$ ) glass microfiber filters (GMF, $2 \mu \mathrm{m}$ ) and glass fiber filters (GF/F, $0.7 \mu \mathrm{m})$ using polyethylen syringes. Filtered samples were acidified to $\mathrm{pH} 2$ with $\mathrm{HCl}$ (p.a.) and stored in polycarbonate bottles (acid-rinsed) at $4{ }^{\circ} \mathrm{C}$ in the dark. Samples for colored dissolved organic matter (CDOM) analysis in pore waters were 
immediately filtered using a glass syringe and pre-combusted $\left(400{ }^{\circ} \mathrm{C}\right.$, $4 \mathrm{~h}$ ) glass fiber filters (GF/F, $0.7 \mu \mathrm{m})$ as pre-filter and $0.2 \mu \mathrm{m}$ Nuclepore track-etched membrane filters. Sample bottles, acid-rinsed prior to use and then rinsed with filtered sample, were stored at $4{ }^{\circ} \mathrm{C}$ in the dark until analysis.

\subsection{Numerical modeling}

Numerical density-dependent flow and transport modeling was carried out for a two-dimensional vertical cross-section of the studied transect, and aimed to identify the principle flow patterns and residence times. The observed groundwater levels thereby served as calibration constraints. Modeling was carried out with the USGS groundwater modeling code SEAWAT (Langevin et al., 2007). The horizontal extent of the model domain was $700 \mathrm{~m}$, i.e., from the dunes to $400 \mathrm{~m}$ offshore (Fig. S1). The spatial discretization in horizontal direction ranged from $4 \mathrm{~m}$ near the southern and northern boundaries of the model to $1 \mathrm{~m}$ in the intertidal zone. The aquifer base was set to $44 \mathrm{~m}$ below mean sea level (mbsl), consistent with the presence of a more or less continuous clay layer at $44-55$ mbsl that acts as an aquitard (Röper et al., 2012). The spatial discretization in vertical direction ranged from $2 \mathrm{~m}$ in the deeper parts of the aquifer to $0.25 \mathrm{~m}$ in the shallow subsurface. Fresh groundwater entered from the South with a flow rate of $0.5 \mathrm{~m}^{3}$ per day and meter of shoreline, estimated from the approximate distance to the groundwater divide (500 $\mathrm{m}$ inland from the southern model boundary) and an approximate recharge rate of $350 \mathrm{~mm}_{\text {year }}{ }^{-1}$ (Röper et al., 2012). Seasonal variations in the groundwater recharge were not considered. Because the groundwater flow and solute transport time scales in the subterranean estuary are orders of magnitude larger than those of the tidal seawater level changes, flow and transport in the beach subsurface are mainly driven by the phase-averaged (i.e., average over a tidal cycle) hydraulic gradients (Vandenbohede and Lebbe, 2006). Therefore, when focusing on the principle groundwater flow and transport patterns, it is sufficient to calibrate the hydraulic model against the phase-averaged measured groundwater levels, rather than the propagation of the tidal wave into the aquifer. An idealized semi-diurnal tide with a 14-day neap-spring tidal cycle was simulated with the SEAWAT-periodic boundary condition package (Mulligan et al., 2011; Post, 2011). Storm floods and wave action were not accounted for.

During model calibration only the horizontal and vertical hydraulic conductivities, as well as the specific yield (unconfined storage coefficient), were adjusted. The transport parameters, i.e., effective porosity and longitudinal and transverse dispersivity were set fixed consistent with literature values for beach zones (e.g., Robinson et al., 2006). In agreement with the results of the grain size analysis (Fig. 2), we assumed homogeneity in the entire model domain. The simulation time was 700 days and ensured the simulation results being at a dynamic equilibrium and independent from the initial conditions. With a rootmean-square error of RMS $=0.11 \mathrm{~m}$ and a Nash-Sutcliffe-Parameter of NS $=0.95$ we obtained a model sufficiently calibrated for the purpose of the study. However, the largest deviation was found for GWM3, since the de-saturation of a ridge located $100 \mathrm{~m}$ afar from the mean sea level mark during ebb tide was not captured well by the model. Details of model parameters and their estimated and applied values, flow and boundary conditions, and calibration results are given in the supporting information (Table S1, Figs. S1, S2).

\subsection{Sample analyses}

\subsubsection{Grain size analysis}

Sediments were sampled in regular intervals (9-12 cm) of each lithological unit, i.e., sediment layers defined by sharp boundaries and a specific particle composition, color, and grain size. Sediment particle sizes were analyzed with a HORIBA LA-950 laser diffraction particle size analyzer following the method applied in Reckhardt et al. (2015).
2.4.2. Quantitative and qualitative analysis of dissolved and particulate organic matter

Dissolved organic carbon (DOC) was quantified on triplicate subsamples of filtered and acidified water samples using high temperature catalytic oxidation on a Shimadzu TOC-VCPH instrument with an analytical accuracy and precision better than $5 \%$. The remaining sample was extracted in $\sim 500 \mathrm{ml}$ aliquots via styrene divinyl benzene polymer filled cartridges (Agilent Bond Elut PPL, $1 \mathrm{~g}$ ) following the procedure of Dittmar et al. (2008). The stable carbon isotope composition was determined on solid phase extracted DOC (SPE-DOC) as outlined in Seidel et al. (2014)

Ultrahigh resolution mass spectrometry was applied to characterize the molecular DOM composition. DOM extracts were diluted with ultrapure water and methanol (MS grade) to yield a DOC concentration of $20 \mathrm{mg} \mathrm{C}^{-1}$ and a methanol to water ratio of $1: 1(\mathrm{v} / \mathrm{v})$ for analysis on a solariX FT-ICR-MS (Bruker Daltonik GmbH, Bremen, Germany) connected to a $15 \mathrm{~T}$ superconducting magnet (Bruker Biospin, Wissembourg, France). Instrument settings and raw data processing were described in Seidel et al. (2014). For this study, we considered peaks with a signal-to-noise $(\mathrm{S} / \mathrm{N})$ ratio of $\geq 4$ and detection in $>3$ samples. Peak intensities were normalized to the sum of peak intensities in each sample.

Molecular DOM composition was statistically analyzed using the free software PAST (Hammer et al., 2001). Cluster analysis was based on Bray Curtis dissimilarity of presence and abundance distribution of individual detected masses in each sample.

Absorbance of CDOM was measured using quartz cuvettes with a path length of $0.05 \mathrm{~m}$ (at site $1 \mathrm{a} 0.01 \mathrm{~m}$ cell was used if the sample volume was very small) and an UV-VIS-spectrophotometer (UV-2700, Shimadzu). Samples were scanned at slow scan speed with an increment of $0.5 \mathrm{~nm}$ in the spectral range between 200 and $800 \mathrm{~nm}$. Ultrapure water was used as reference. Absorbance values $A(\lambda)$ were baseline corrected and then converted to the absorption coefficient $a_{\mathrm{CDOM}}(\lambda)$ according to $a_{\mathrm{CDOM}}(\lambda)=2.303 \times A(\lambda) / l$, where $\lambda$ is the wavelength and $l$ is the path length of the cuvette in meters (Kirk, 2011). Based on this spectral information the CDOM absorption coefficient at $275 \mathrm{~nm}$ and $440 \mathrm{~nm}$ as well as the spectral slope $\left(\mathrm{S}_{\mathrm{CDOM}}\right)$ in the spectral range of 275-295 nm were deduced (Garaba et al., 2014). Additionally the slope ratio $\left(S_{R}\right)$ defined by Helms et al. (2008) as the ratio $\mathrm{S}_{\mathrm{CDOM}(275-295 \mathrm{~nm})} / \mathrm{S}_{\mathrm{CDOM}(350-400 \mathrm{~nm})}$ was derived. Precision and accuracy of the analyses were $<5 \%$.

Sediment samples were freeze-dried and homogenized in an agate mill. Total carbon was determined using a carbon analyzer (vario El cube, Elementar Analysensysteme $\mathrm{GmbH}$ ), and the total inorganic carbon was analyzed coulometrically (UIC, Joliet, USA). Total organic carbon was calculated as the difference between total carbon and total inorganic carbon. The precision and accuracy of the analyses were $<3 \%$.

\subsubsection{Oxygen concentrations and consumption rates}

Oxygen $\left(\mathrm{O}_{2}\right)$ concentrations were measured with optode microsensors (Pyroscience, sensor type OXR 430 HS) that were introduced into the sediment cores immediately after retrieval by drilling holes into the aluminum liner. In addition, high resolution vertical $\mathrm{O}_{2}$ profiles were measured at site 3 to resolve the shallow $\mathrm{O}_{2}$ penetration depth. Furthermore, pore water was retrieved using a push point sampler at sites 2 and 4 and $\mathrm{O}_{2}$ was measured using an optical $\mathrm{O}_{2}$ flow through sensor (Pyroscience, sensor type OXFTC).

$\mathrm{O}_{2}$ consumption rates of surface sediments (upper $5 \mathrm{~cm}$ ) from sites 3 and 2 were determined after Marchant et al. (2014) using flow through columns of $10 \mathrm{~cm}$ diameter and $20 \mathrm{~cm}$ length. The flow through columns were filled with sand while completely submerged in seawater to prevent the trapping of air bubbles. Using a peristaltic pump air saturated surface water was pumped through the flow through columns with flow rates adjusted to 8.2 and $9.1 \mathrm{ml} \mathrm{min}^{-1}$. This corresponds to a pore water flow of $470-520 \mathrm{~cm} \mathrm{~d}^{-1}$, which is comparable to the modeled flow velocity in the USP. $\mathrm{O}_{2}$ concentrations were measured 
at in- and outlet using optical $\mathrm{O}_{2}$ flow through sensors (Pyroscience, sensor type OXFTC). $\mathrm{O}_{2}$ consumption rates were calculated by dividing the $\mathrm{O}_{2}$ difference between in- and outlet by the retention time, which was on average $1 \mathrm{~h}$.

\subsubsection{Analyses of dissolved nutrients, sulfate, hydrogen sulfide, and trace elements}

Dissolved Fe, Mn, Si, and P were analyzed using inductively coupled plasma optical emission spectrometry (ICP-OES, Thermo Scientific). Samples with low Fe and Mn concentrations were additionally measured by inductively coupled plasma mass spectrometry (ICP-MS, Thermo Finnigan MAT). The $\mathrm{SO}_{4}^{2-}$ concentration was determined by ion chromatography (IC, Metrohm) and sulfide was measured after Cline (1969). Nutrients $\left(\mathrm{NH}_{4}^{+}, \mathrm{NO}_{2}^{-}, \mathrm{NO}_{\mathrm{x}}^{-}\right.$and total alkalinity) were analyzed as described in Reckhardt et al. (2015). Accuracy and precision was $<10 \%$ for all measurements.

Rare earth element (REE) samples were spiked with a multi-element REE isotope spike (DKM, prepared by Gilbert N. Hanson of SUNY Stony Brook) and allowed to equilibrate for at least $48 \mathrm{~h}$. A UV $/ \mathrm{H}_{2} \mathrm{O}_{2}$-oxidation was applied for $24 \mathrm{~h}$ to destroy organic matter in the samples. The REEs were then preconcentrated from seawater using an automated seaFAST system (Elemental Scientific Inc.) following a method modified from Hathorne et al. (2012). The REEs were analyzed and quantified by isotope dilution ICP-MS using a Thermo Element 2 and a Cetac Aridus II desolvating nebulizer to reduce the oxide formation to $<0.04 \%$ for Ce. The external reproducibility $(2 \sigma)$, determined by repeated processing and analysis of seawater samples from BATS (Bermuda Atlantic Times Series station) from $20 \mathrm{~m}$ and $2000 \mathrm{~m}$ water depth, was $<10 \%$ for all REEs except for Ce $(<18 \% ; n=5)$. Our analyses were within the $8 \%$ range of the consensus values of the BATS samples (Pahnke et al., 2012; Van de Flierdt et al., 2012). Procedural blanks were $<4 \%$ for all REEs except for the lowest measured Ce concentration $(<10 \%)$. The Ce-anomaly was calculated as $\mathrm{Ce} / \mathrm{Ce}^{*}=3^{*} \mathrm{Ce}_{\text {PAAS-norm. }} /\left(2^{*}\right.$ La PAASnorm. $+\mathrm{Nd}_{\text {PAAS-norm. }}$ ) after German et al. (1995) using PAAS-normalized values (Post-Archean Australian Shale, Taylor and McLennan, 1985).

To present salinity, DOC, nutrient, $\mathrm{SO}_{4}^{2-}$, and trace element data, concentrations below the limit of quantification were set to zero, which is appropriate considering the wide concentration range we present here for each element. On the basis of these data sets contour plots were created using the interpolation mode v4 (biharmonic spline interpolation) of MATLAB R2013b (The MathWorks Inc., Natick, MA). Additionally, the concentration at each pore water extraction location was plotted color-coded onto the interpolated area to emphasize the exact value.

\subsubsection{Particulate nutrient and chlorophyll a analyses}

For analyzing particulate nutrient and chlorophyll $a$ concentrations of the benthic microalgae community, microalgae were separated from the sediment. Microscopic investigations ensured that the samples contained mostly benthic algae and not phytoplankton, which might have settled on the sediment. Seawater $(0.2 \mu \mathrm{m}$ filtered) was added to the sediment samples and these samples were stirred and placed in an ultrasonic bath (20 min). Afterwards the overlaying suspension was decanted. This was done three times and the overall suspension of each sample was filtered onto pre-combusted, acid-washed glass fiber filters (Whatman GF/F). These filters were stored at $-20{ }^{\circ} \mathrm{C}$ until further analysis.

Particulate organic phosphorus (POP) was measured after muffling the filters at $550{ }^{\circ} \mathrm{C}$ for $24 \mathrm{~h}$ by molybdate reaction after sulfuric acid digestion (Wetzel and Likens, 2003). Particulate organic carbon (POC) was measured using a CN elemental analyzer (Thermo Flash EA 1112). Chlorophyll $a$ (Chl $a$ ) concentrations were measured photometrically after extraction with acetone (Wetzel and Likens, 2003). To be able to compare concentrations of POP, POC, and Chl $a$ among transects and stations we normalized these concentrations, based on the mean value of each parameter for each transect, and log transformed them.

\subsubsection{Total bacterial cell counts and microbial community analysis}

For total cell counts, $0.5 \mathrm{~cm}^{3}$ sediment was fixed with $2 \%$ formaldehyde overnight. The sediment was centrifuged and washed three times with $1 \times$ phosphate-buffered saline (PBS; $145 \mathrm{mM} \mathrm{NaCl}, 1.4 \mathrm{mM}$ $\mathrm{NaH}_{2} \mathrm{PO}_{4}, 8 \mathrm{mM} \mathrm{Na}_{2} \mathrm{HPO}_{4}$, pH 7.4). Samples were stored in PBS/ethanol $(\mathrm{v} / \mathrm{v}, 2: 3)$ at $-20^{\circ} \mathrm{C}$. For SybrGreen staining, the samples were sonicated three times each for $1 \mathrm{~min}$. After settling of the sand particles, the supernatant containing the cells was transferred to another vial. In this way, the sediment was washed six times with PBS and the supernatants combined. Cells from the supernatant were filtered onto $0.1 \mu \mathrm{m}$ Nuclepore polycarbonate filters and stained with SybrGreen solution directly on the object slide. For each sample, at least 400 cells were counted by epifluorescence microscopy.

DNA was extracted from $0.5 \mathrm{~cm}^{-3}$ frozen sediment with PowerSoil DNA Isolation Kit (MoBio) according to the manufacturer's instructions. Polymerase chain reaction (PCR) for denaturing gradient gel electrophoresis (DGGE) was performed with 31-41 cycles (depending on the final DNA concentration of the PCR products) with primers 357F with GC clamp and 907R (Muyzer et al., 1995) for bacterial 16S rRNA genes, primers Arch-amoAF and Arch-amoAR (Francis et al., 2005) for archaeal amoA genes, primers amoA-1F and amoA-2R (Rotthauwe et al., 1997) for betaproteobacterial amoA genes, primers aprA-1-FW-GC and aprA5-RV with GC clamp (Meyer and Kuever, 2007) for aprA genes. For archaeal 16S rRNA genes, a nested PCR was performed according to Nicol et al. (2003). For the first PCR primers Ar3F and Ar9R were used with 25 cycles, PCR products were purified with QIAquick PCR purification kit (Qiagen) and used for the second PCR with primers SAf and PARCH519r and 37-44 cycles. The specificity of the primer sets was tested by excision of single DGGE bands, reamplification and sequence analysis.

DGGE was performed with PCR products loaded onto 6\% polyacrylamide gels in $1 \times$ TAE buffer ( $40 \mathrm{mmol} \mathrm{l}^{-1}$ Tris, $1 \mathrm{mmol} \mathrm{l}^{-1}$ EDTA, $\mathrm{pH} 7.4$ ) with a denaturing gradient from 50 to $70 \%$ (with $100 \%$ denaturant corresponding to $7 \mathrm{M}$ urea and $40 \%$ formamide) at $100 \mathrm{~V}$ and $60{ }^{\circ} \mathrm{C}$ for $20 \mathrm{~h}$ for bacterial $16 \mathrm{~S}$ rRNA genes, $15-55 \%$ for $15 \mathrm{~h}$ for archaeal amoA genes, $30-60 \%$ for $20 \mathrm{~h}$ for betaproteobacterial amoA genes, and $40-70 \%$ for $20 \mathrm{~h}$ for aprA genes. For PCR products of archaeal 16S rRNA genes, the gel consisted of $8 \%$ polyacrylamide with a denaturing gradient from 35 to $80 \%$ and ran for $20 \mathrm{~h}$. Gels were stained in $1 \times$ SybrGold solution in $1 \times$ TAE buffer and washed for $30 \mathrm{~min}$ in distilled water. The band patterns were analyzed by cluster analysis using the software package GelComparII (Applied Maths) as described by Wilms et al. (2006).

\section{Results}

\subsection{Sedimentology}

Beach sediments consist of quarzitic fine to medium grained sand (mean grain sizes 170-320 $\mu \mathrm{m}$; Fig. 2). Shells or shell debris are found in all cores and they occur as distinct layers or are finely dispersed. Stratification is best visible where layers of coarser-grained sand, heavy minerals, or organic-rich mud are intercalated in the fine sand. The mud pebbles originate from erosion of subfossil semi-consolidated mud beds (Hellwig and Stock, 2014). Internal sedimentary structures are restricted to even lamination.

\subsection{Modeling of groundwater flow and residence times}

The model results (Fig. 3) reflect the typical hydrological zonation of beaches with an upper saline plume (USP), a terrestrial groundwater flow and freshwater discharge tube, and a saltwater wedge as proposed by Robinson et al. (2007a, 2007b). At our study site, the modeled USP reaches a depth of about $20 \mathrm{~m}$. The subsurface residence times in the USP are in the order of weeks to months, depending on the depth of the respective flow-paths (Fig. 3), and the phase-averaged pore water velocities at the entry points reach approximately $0.3-0.7 \mathrm{~m} \mathrm{~d}^{-1}$. In contrast, the residence times in the saline wedge are in the order of 

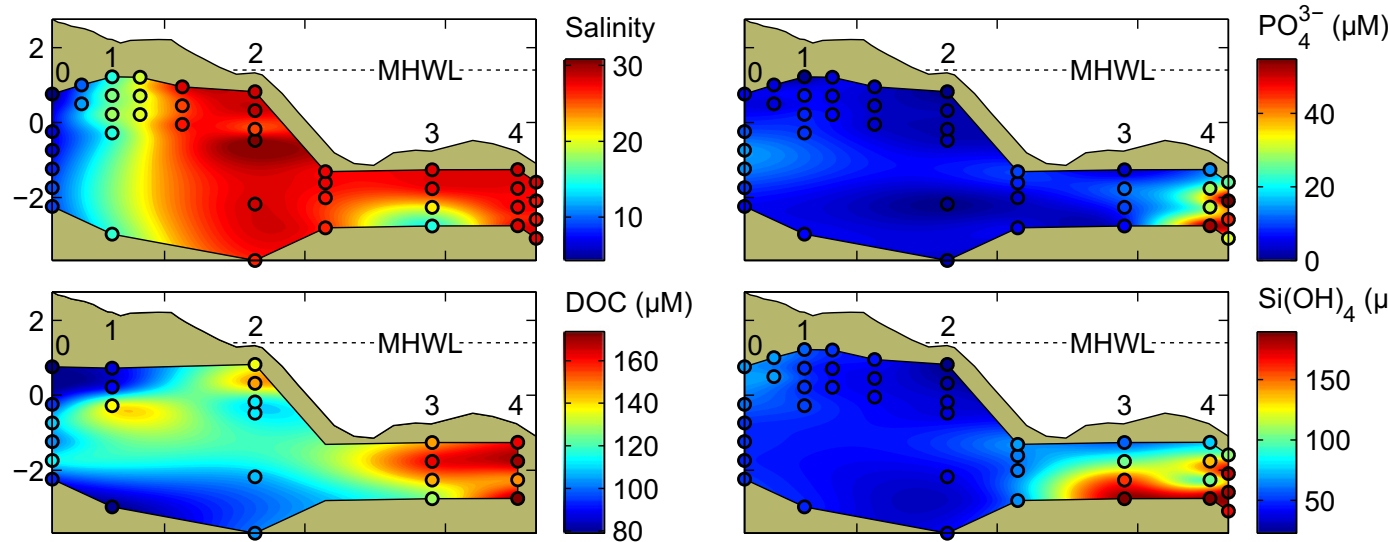

$\mathrm{DOC}(\mu \mathrm{M})$
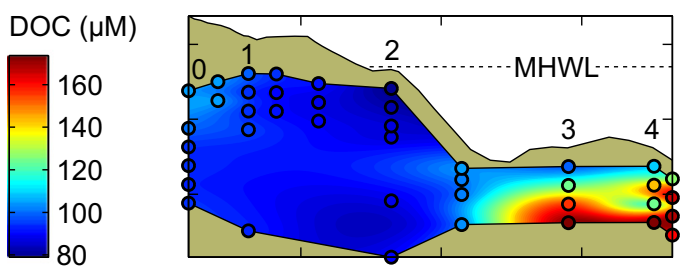

$\mathrm{Si}(\mathrm{OH})_{4}(\mu \mathrm{M})$

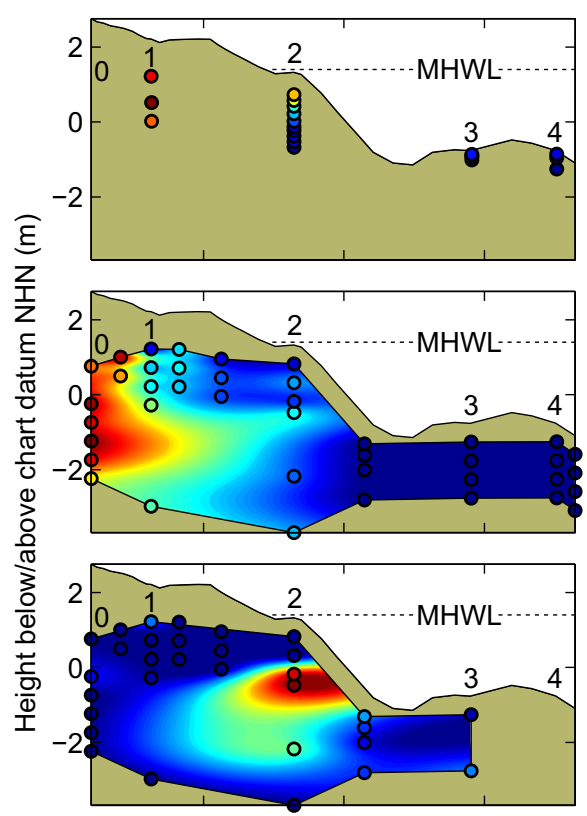

$\mathrm{O}_{2}(\%)$

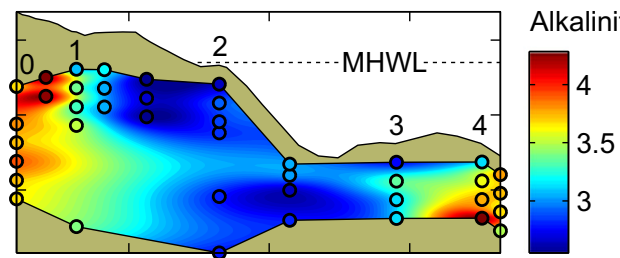

150

$-100$

50

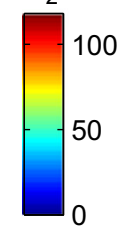

$\mathrm{NO}_{\mathrm{x}}^{-}(\mu \mathrm{M})$

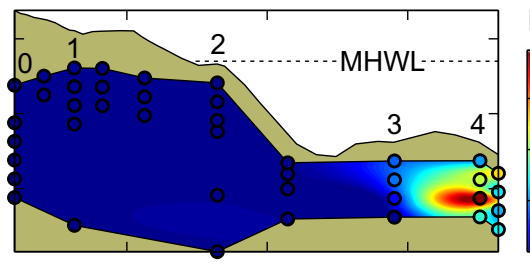

$\mathrm{Mn}(\mu \mathrm{M})$
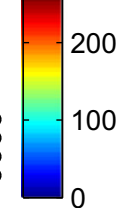

$\mathrm{NO}_{2}^{-}(\mu \mathrm{M})$
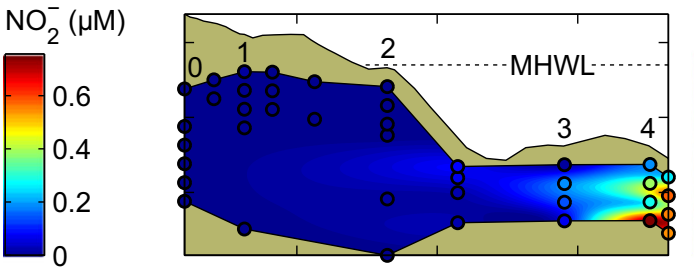

$\mathrm{Fe}(\mu \mathrm{M})$

$-60$

$-40$

$-20$

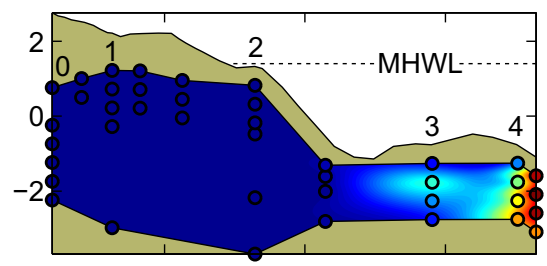

$\mathrm{NH}_{4}^{+}(\mu \mathrm{M})$
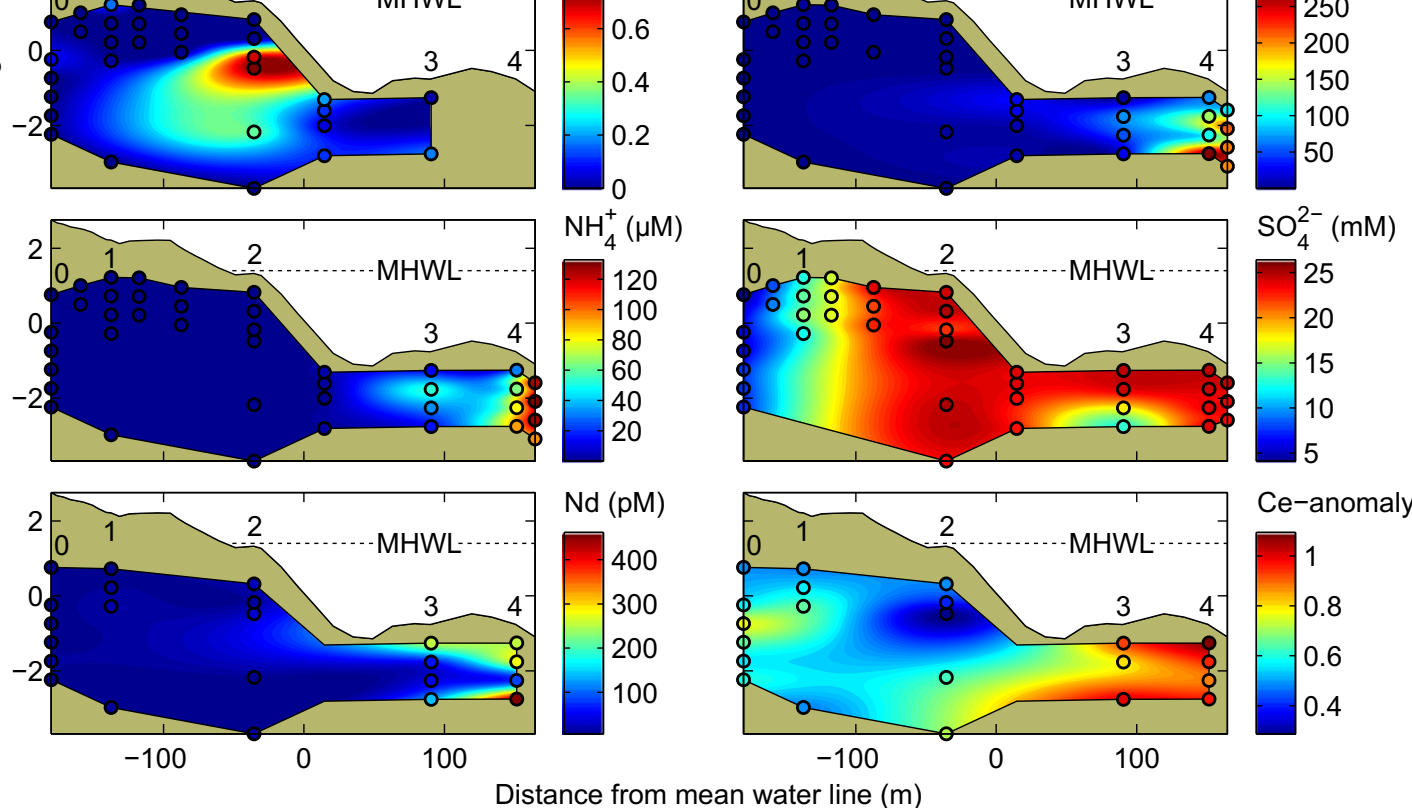

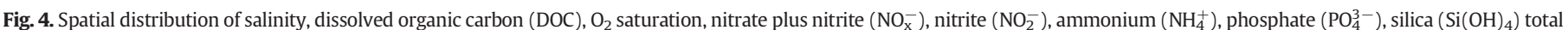

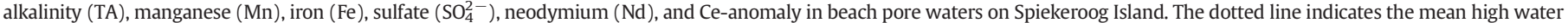

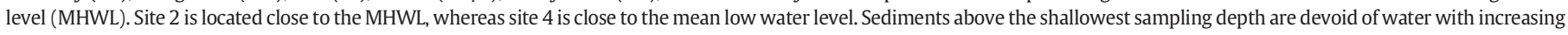
distance from the low-water line.

years to decades. The residence time of the fresh groundwater from the dune base to the discharge point is approximately $6-13$ years, whereby the last section of the flow path, i.e., the freshwater discharge tube is passed within less than a year. Fresh groundwater originating from the island's freshwater lens displays a typical age stratification, with a maximum groundwater age of $>40$ years in the deepest part of the freshwater lens according to tritium-helium dating (Röper et al., 2012). Below the beach, this old freshwater and the much younger 

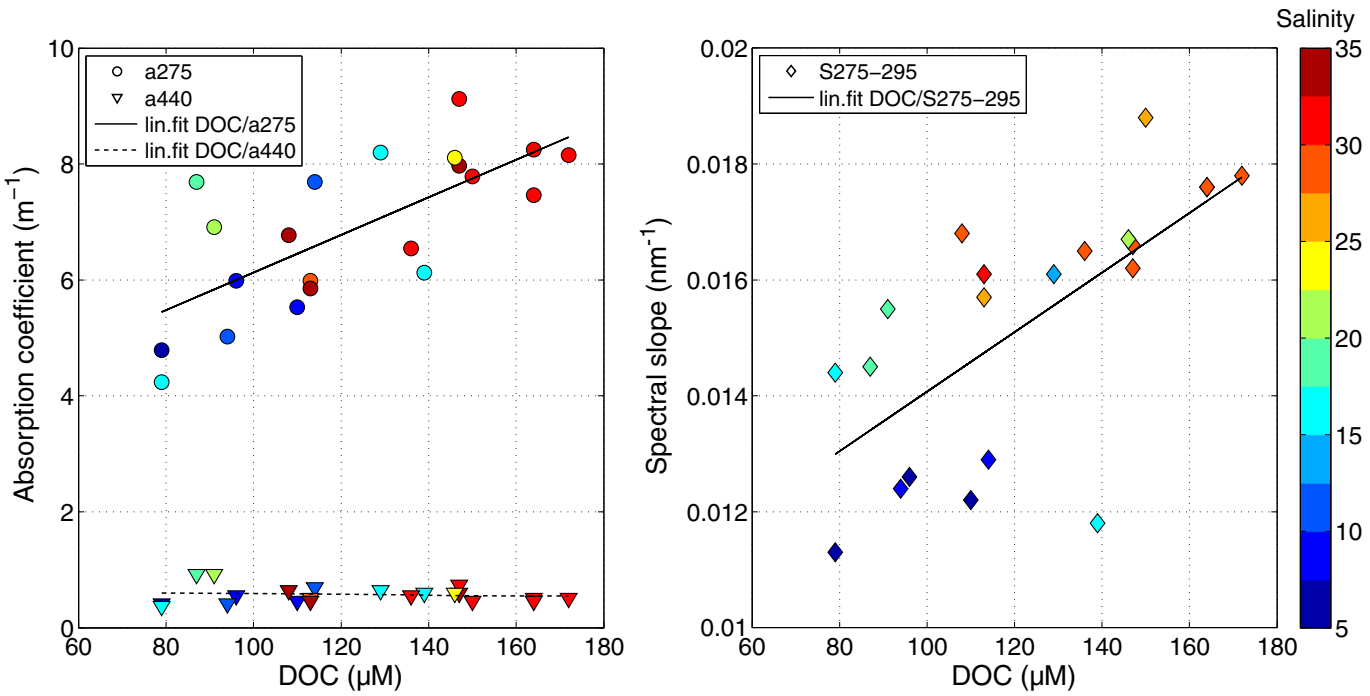

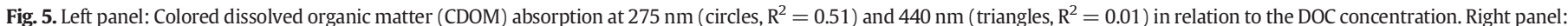
Spectral slope between 275 and $295 \mathrm{~nm}$ (diamonds, $\mathrm{R}^{2}=0.45$ ) in relation to DOC. Both panels use color coded symbols to represent salinity.

freshwater from shallower parts become well mixed in the freshwater discharge tube, where they also mix with the very young saltwater of the USP and the older water from the lower salt water wedge.

The position of the freshwater discharge tube requires further investigations because the model proposes its position at the beach runnel, whereas less saline water was determined by pore water analysis approximately $50 \mathrm{~m}$ seaward from the model-predicted discharge point (Figs. 3, 4). The deviation between model and measurements may be attributed to the simplification of the seaward and landward flow boundary conditions in the model, i.e., neglect of seasonal groundwater recharge and storm surges. It is also possible that the freshwater discharge point shifted with time due to changes in beach morphology on longer time scales, leaving residual brackish water at the location of the earlier freshwater discharge point.

A groundwater flow divide exists at the ridge of the beach transect. This leads to varying residence times of $<6$ years and up to 25 years on the landward and seaward sides of the divide, respectively. The simulated residence time distribution below the ridge has to be regarded as rough estimate due to the overestimation of the phase-averaged hydraulic head at GWM3 (Fig. 3).

The analysis of the model's water budget reveals that the saltwater flux through the USP is approximately $2.8 \mathrm{~m}^{3}$ per day and meter of shoreline. From the ridge the total saltwater flux of $1.5 \mathrm{~m}^{3}$ per day and meter of shoreline is diverted to the runnel and to the seaside, with 0.5 and $1.0 \mathrm{~m}^{3}$ per day and meter of shoreline, respectively. The total fresh water discharge is $0.75 \mathrm{~m}^{3}$ per day and meter of shoreline. The overall error in the model-based estimation of SGD fluxes as a result of model assumptions, i.e., estimation of fresh groundwater flux, neglecting waves and storm floods, as well as the calibration performance, can be considered as being roughly 0.5 to 2 times the derived values. This error estimation is based on findings by Xin et al. (2010) who found in their modeling analysis that the total SGD rate increased by $33 \%$ when waves and tides were considered compared to tides alone. Furthermore, the saline SGD rate through the upper saline plume doubled.

\subsection{Pore water chemistry}

\subsubsection{Salinity and dissolved organic matter}

Salinities are $<10$ in vicinity of the dunes and reach 31 in the intertidal zone (Fig. 4). At site 3, salinity decreases distinctly to about 15 below $1 \mathrm{~m}$ sediment depth. Dissolved organic carbon (DOC) concentrations range between 80 and $175 \mu \mathrm{M}$ and are highest close to the mean low water level (Fig. 4). CDOM absorption at $275 \mathrm{~nm}$ ranges between
$4.2 \mathrm{~m}^{-1}$ and $9.5 \mathrm{~m}^{-1}$ and is related to DOC concentrations and salinity (Fig. 5), while absorption at $440 \mathrm{~nm}$ stays nearly constant ( $0.6 \pm$ $0.4 \mathrm{~m}^{-1}$ ) for all samples. The slope of the CDOM absorption spectra at 275 to $295 \mathrm{~nm}$ ranges from $0.011 \mathrm{~nm}^{-1}$ at low DOC and salinity levels to $0.019 \mathrm{~nm}^{-1}$ for higher DOC concentrations and salinities (Fig. 5). The slope ratio $S_{R}$ is below 1.0 for salinities $<17$ and above 1.0 for higher salinities.

\subsubsection{Oxygen saturation, consumption, and flux}

At site 1, pore water between 1 and $2.2 \mathrm{~m}$ depth (sediments were only water saturated below $1 \mathrm{~m}$ depth) is $\mathrm{O}_{2}$ saturated showing no trend with depth (Fig. 4). At site 2, $\mathrm{O}_{2}$ saturation decreases from 60 to $80 \%$ at $0.6 \mathrm{~m}$ to $2 \%$ at $2 \mathrm{~m}$ depth. At site $3, \mathrm{O}_{2}$ saturation is $60-100 \%$ in surface sediments down to $4.5 \mathrm{~cm}$. Further below, it decreases rapidly to below $5 \%$ at $13 \mathrm{~cm}$ depth. At site $4, \mathrm{O}_{2}$ is below $10 \%$ at $10 \mathrm{~cm}$ and $0.7 \%$ at $50 \mathrm{~cm}$ depth. $\mathrm{O}_{2}$ respiration experiments using flow through columns show that $\mathrm{O}_{2}$ concentrations at the outlet of the columns are in steady state after $1-2 \mathrm{~h}$ of pumping. The $\mathrm{O}_{2}$ differences between inand outlet are $44 \mu \mathrm{M}$ (site 2) and $133 \mu \mathrm{M}$ (site 3 ) and from the pore water retention time of $1 \mathrm{~h}$, potential $\mathrm{O}_{2}$ consumption rates of $44 \mu \mathrm{M} \mathrm{h}^{-1}$ and $133 \mu \mathrm{M} \mathrm{h}^{-1}$ can be calculated. Assuming steady state conditions, the rate can be integrated over the $\mathrm{O}_{2}$ penetration depth to estimate the $\mathrm{O}_{2}$ flux. The resulting $\mathrm{O}_{2}$ fluxes are $9.3 \mathrm{mmol} \mathrm{m}^{-2} \mathrm{~h}^{-1}$ at site 3 and $84 \mathrm{mmol} \mathrm{m}^{-2} \mathrm{~h}^{-1}$ at site 2 . However, for the latter site the calculated flux likely overestimates the true flux as we assumed that the $\mathrm{O}_{2}$ consumption rates measured in the surface sediments $(0-$ $5 \mathrm{~cm}$ ) were the same for the entire oxic sediment layer from 0 to $1.9 \mathrm{~m}$.

\subsubsection{Inorganic nutrients}

Dissolved inorganic nitrogen consists mainly of $\mathrm{NO}_{3}^{-}$near the dune and concentrations decrease with increasing salinity towards the low-water line, where inorganic nitrogen is comprised mostly of $\mathrm{NH}_{4}^{+}$ (Fig. 4). At site 2, $\mathrm{NO}_{2}^{-}$concentrations are highest (Fig. 4). $\mathrm{PO}_{4}^{3-}$, $\mathrm{Si}(\mathrm{OH})_{4}$, and total alkalinity concentrations increase from the duneward part to the low water line (Fig. 4). Additionally, $\mathrm{Si}(\mathrm{OH})_{4}$ concentrations increase significantly at site 3 , coincidently with decreasing salinity.

\subsubsection{Redox-sensitive trace metals and sulfate}

Dissolved Mn and Fe concentrations increase from the backshore towards the low-water line and attain maximum concentrations at the low-water line (Fig. 4). The spatial $\mathrm{SO}_{4}^{2-}$ distribution resembles the salinity distribution (Fig. 4) and sulfide was below the limit of quantification $(<2 \mu \mathrm{M})$ in all samples (data not shown). 

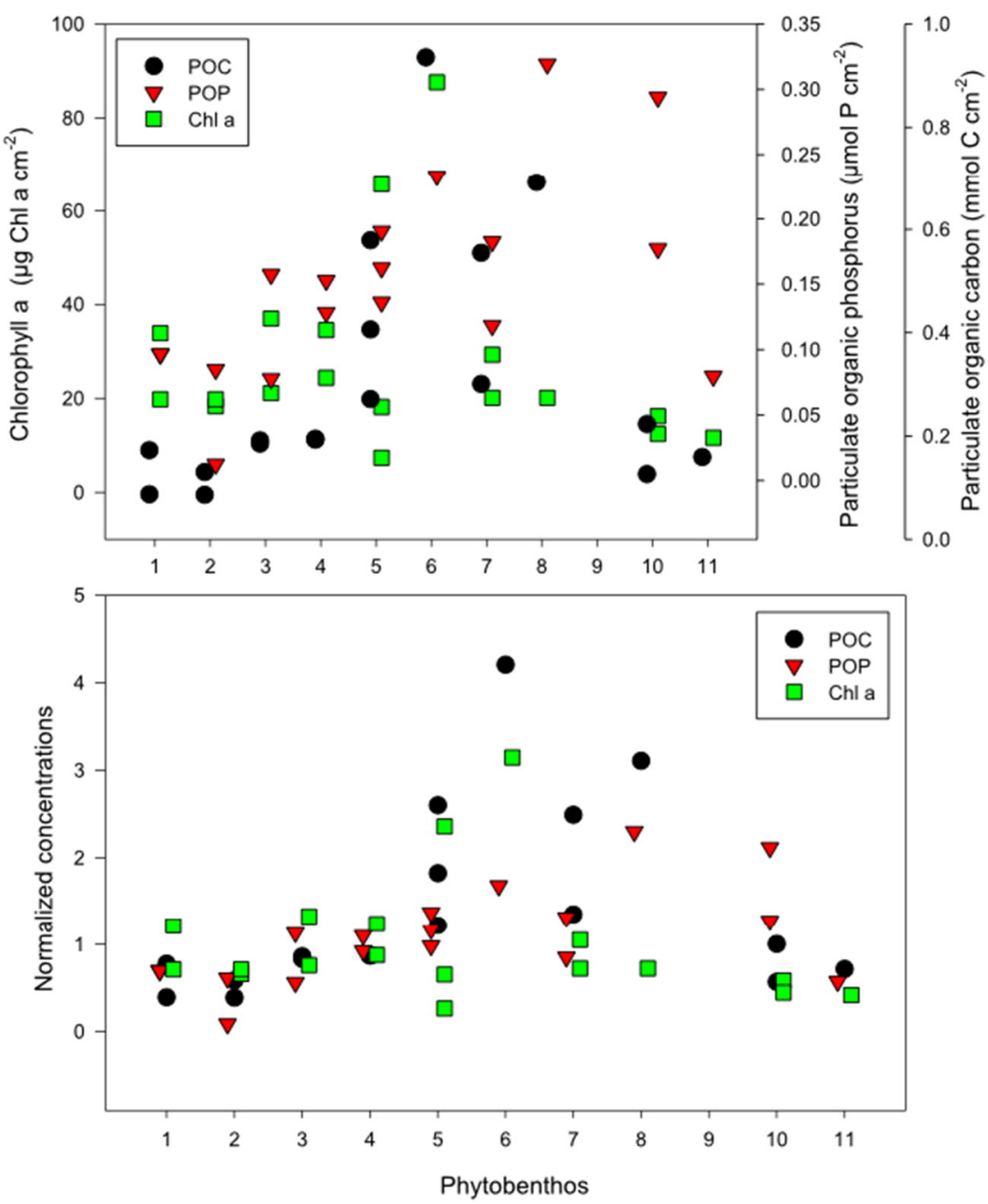

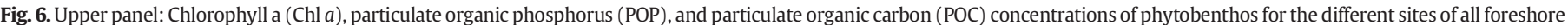

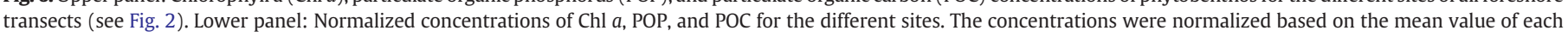

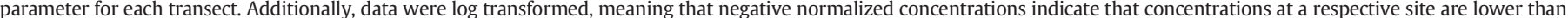

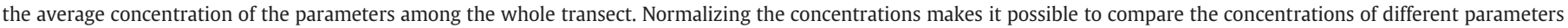
among transects and sites.

Besides Mn, Fe, and sulfate, rare earth elements can be used to classify the redox regime of pore waters. Ce is oxidized to insoluble Ce(IV) and removed from the dissolved phase under oxic conditions, leading to a depletion relative to its neighbor elements and hence to negative Ce-anomalies (e.g., Elderfield, 1988; Haley et al., 2004). Nd is scavenged by organic and inorganic particles from oxic water due to its high particle reactivity (e.g., Elderfield, 1988). Under suboxic/anoxic conditions, Ce oxides dissolve and $\mathrm{Nd}$ is released from particles leading to positive or no Ce-anomalies and elevated Nd concentrations. Along the beach transect, the Ce-anomaly shows a separation between sites $0 / 1$ and sites $3 / 4$ (Fig. 4). In the backshore (sites $0 / 1$ ), negative Ce-anomalies $(<1)$ are found, whereas at sites $3 / 4$, Ce-anomalies are absent or slightly positive ( $>1)$. A similar spatial distribution is apparent for $\mathrm{Nd}$ with concentrations almost one order of magnitude higher at sites $3 / 4$ than at the other sampling locations (Fig. 4).

\subsection{Benthic chlorophyll a and particulate nutrients}

Chlorophyll $a$, particulate organic phosphorus (POP), and particulate organic carbon (POC) concentrations of phytobenthos (Fig. 6 upper panel) tend to increase from the mean high water level towards the site located in the runnel (phytobenthos site 6) draining the emerged parts of the beach during falling tide and decrease again at sites located closer to the mean low water level. The normalized POP, POC and Chl $a$ concentrations differ significantly between sites (ANOVA, $p<0.001$ ). Especially the site located in the middle of the runnel (phytobenthos site 6) is significantly different compared to sites closer to the high and low water lines (TukeyHSD PostHoc Test, $p<0.01$; Fig. 6 lower panel).

\subsection{Cell counts and microbial diversity}

Total bacterial cell counts range between $1.4 \times 10^{7}$ and $2.6 \times 10^{8}$ cells $\mathrm{cm}^{-3}$ sediment. Generally, they are lower at sites 0 and 1 than at the other three sites most likely because of the low water content in these sediments. Molecular analysis by using denaturing gradient gel electrophoresis (DGGE) analysis (Figs. 7, S3) reveals distinct vertical and horizontal compositions of microbial communities in the beach subsurface. This molecular technique is based on the sequence-specific separation of gene fragments amplified from an environmental sample. The resulting banding patterns indicate the presence or absence of a certain species that carry the investigated gene. Similarities and differences between the microbial communities can be visualized by cluster analysis of the DGGE banding patterns. Over all samples, the diversity of bacterial $16 \mathrm{~S}$ rRNA genes is generally higher compared to the archaeal, indicating a more complex bacterial community composition on the species level. Besides analyzing this general phylogenetic marker, we additionally studied key genes indicative for metabolic processes to 


\section{bacterial 16S rRNA}

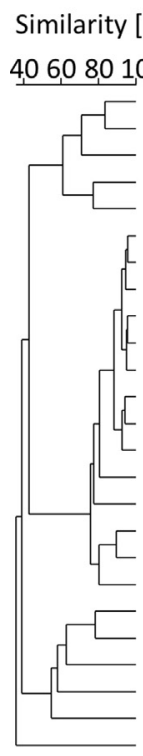

1100

$\begin{array}{ll}1 & 130 \\ 1 & 180\end{array}$

\begin{tabular}{rr}
1 & 180 \\
0 & 150 \\
0 & 200 \\
\hline
\end{tabular}

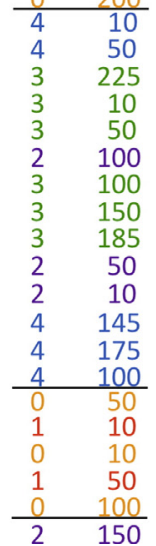

archaeal 165 rRNA

Similarity [\%]

$60 \quad 80100$ Site Depth

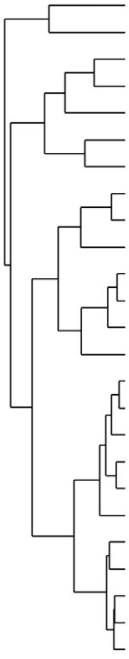

\begin{tabular}{cr}
\hline 1 & 100 \\
1 & 130 \\
\hline 0 & 10 \\
1 & 10 \\
0 & 50 \\
0 & 100 \\
1 & 50 \\
\hline 0 & 150 \\
0 & 200 \\
2 & 150 \\
1 & 180 \\
2 & 50 \\
2 & 10 \\
2 & 100 \\
\hline 3 & 10 \\
3 & 50 \\
3 & 150 \\
4 & 10 \\
4 & 50 \\
4 & 145 \\
3 & 100 \\
3 & 185 \\
3 & 225 \\
4 & 100 \\
4 & 175
\end{tabular}

archaeal amoA

Similarity [\%]

406080100 Site Depth

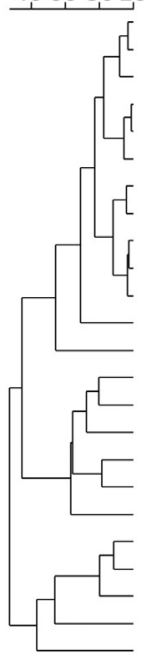

\begin{tabular}{rr}
\hline 3 & 185 \\
3 & 225 \\
4 & 50 \\
3 & 50 \\
3 & 150 \\
3 & 100 \\
2 & 50 \\
2 & 100 \\
2 & 10 \\
4 & 10 \\
3 & 10 \\
4 & 145 \\
4 & 100 \\
\hline 1 & 100 \\
1 & 180 \\
1 & 130 \\
0 & 150 \\
0 & 200 \\
2 & 150 \\
\hline 0 & 50 \\
1 & 50 \\
1 & 10 \\
0 & 100 \\
0 & 10
\end{tabular}

bacterial amoA

Similarity [\%]

$20 \quad 60100$ Site Depth

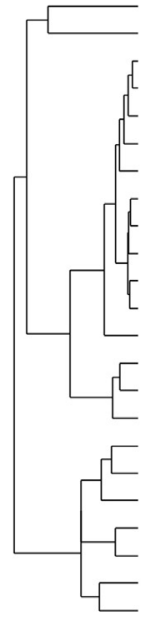

aprA

Similarity [\%]

$20 \quad 60 \quad 100$ Site Depth

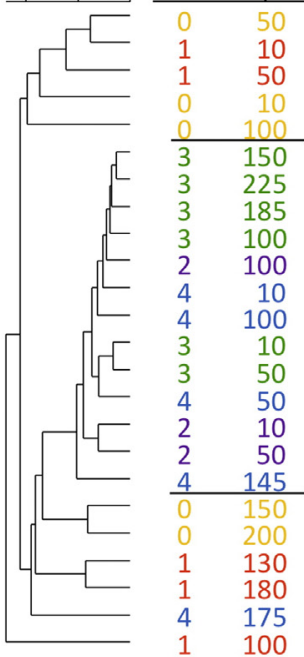

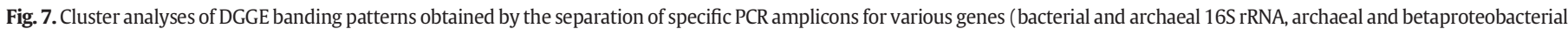

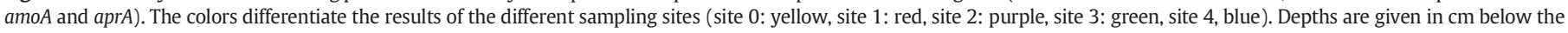

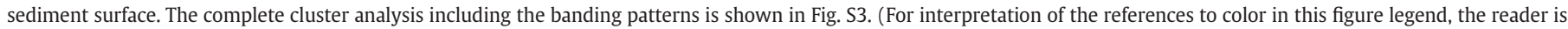
referred to the web version of this article.)

obtain a more detailed view on variations of selected physiologic traits within the microbial communities. The ammonia monooxygenase $(a m o A)$ is involved in the aerobic oxidation of ammonia. Ammoniaoxidizing betaproteobacteria and archaea can specifically be distinguished. The dissimilatory adenosine-5'-phosphosulfate reductase (aprA) is present in $\mathrm{SO}_{4}^{2-}$-reducing and sulfur-oxidizing prokaryotes. Interestingly, independent on the genes analyzed, DGGE banding patterns of sites 0 and 1 as well as 3 and 4 cluster together, indicating unique microbial community compositions in the duneward and seaward parts of the transect (Fig. 7). All depths of site 3 and 4 with all genes analyzed form a coherent cluster. In contrast, samples of all depths of site 2 either cluster with the landward or seaward sites.

\section{Discussion}

\subsection{Beach hydrology and salinity gradients influence the beach ecosystem}

The groundwater flow and transport field (Fig. 3) reveals the typical hydrological zonation of beaches with an USP, the saltwater wedge, and the freshwater discharge tube in between. This zonation is also reflected in the spatial salinity distribution (Fig. 4). In general, such a groundwater flow field is due to nearshore flow processes such as density-driven circulation, tide-induced circulation, wave-setup induced circulation, local circulation due to wave-bed form interaction, and fresh groundwater discharge (Precht and Huettel, 2003; Robinson et al., 2007b).

In response to tidal forcing and beach morphology, the model predicts that the USP reaches a depth of 15-20 m below the beach surface (Fig. 3). Thus, the USP at Spiekeroog beach may extend down to greater depths than previously shown in other studies using salinity measurements and/or hydrological modeling (Charette and Sholkovitz, 2006; Heiss et al., 2014; McAllister et al., 2015; Santos et al., 2008; Ullman et al., 2003). The majority of these studies were, however, carried out in microtidal environments, which may explain why the USP does not reach depths exceeding $5 \mathrm{~m}$.
4.2. Spatial differences in organic matter sources and turnover result from pore water circulation patterns

The stock of particulate organic carbon in the permeable beach sands is very low $(<0.03 \%)$. This indicates that there must be an additional source of organic carbon fueling the microbial activity in the sediments, which is likely the infiltration of dissolved and particulate organic matter $(\mathrm{OM})$ by pore water circulation. Residence times are short in the USP, less than eight months or even shorter in the zone at the mean high water level that is saturated and desaturated at tidal rhythm (Fig. 3). This leads to a continuous resupply of the sediments with OM as indicated by elevated DOC concentrations at site 2 (Fig. 4). The zone of elevated DOC concentrations is, however, relatively narrow. This may be due to a fast recirculation of remineralization products to the water column (Chipman et al., 2010; Ehrenhauss et al., 2004; Seidel et al., 2015). Furthermore, sampling took place several weeks after the main spring phytoplankton bloom, which started at the beginning of March, as reflected in sharply decreasing silicate concentrations at a nearby permanently installed time series station (similar measurements are described in Grunwald et al. (2010) and Beck and Brumsack (2012)). Consequently, the OM of the spring phytoplankton bloom had likely already been processed in the upper sediments of the USP. In contrast to the USP, high DOC concentrations at sites 3 and 4 are not only due to continuous $\mathrm{OM}$ input, but also due to longer pore water residence times in the order of some years in the ridge sediments (Figs. 3, 4), which allow the enrichment of OM remineralization products like DOC and alkalinity.

To determine whether DOM is of marine or terrestrial origin, carbon isotopic compositions of SPE-DOC were analyzed. They fall in a narrow range of -24.1 to $-25.6 \%$ indicating a predominantly marine source of the DOC (seawater endmember $-24.3 \%$ o $(n=4, \sigma=0.07)$, freshwater endmember determined in the freshwater lens of Spiekeroog Island on average $-27.4 \%$ o $(n=14, \sigma=0.8)$. The marine origin of the DOM is further supported by the finding that the molecular composition of pore water DOM is more similar to seawater DOM than to DOM found 


\section{Similarity (Bray Curtis)}

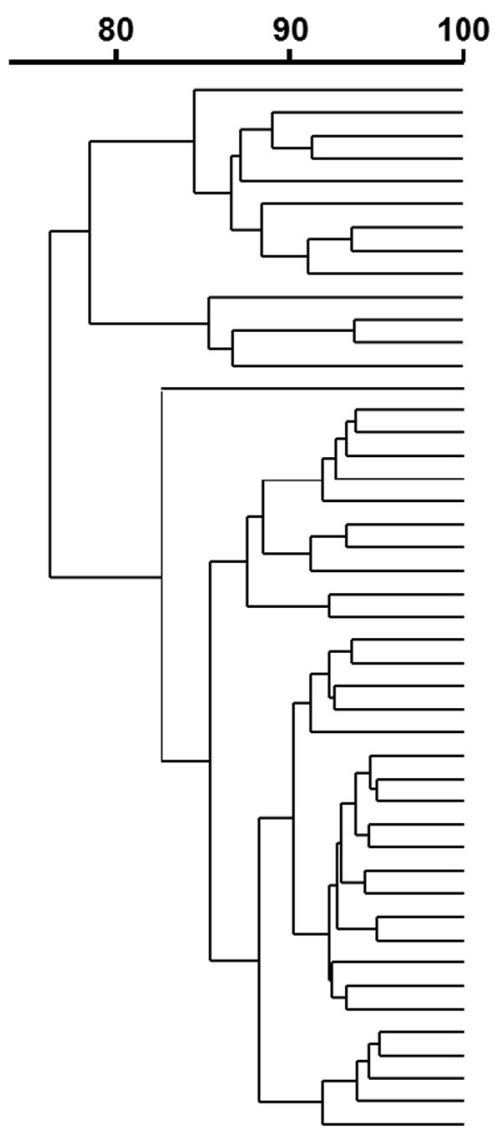

Site Depth $(\mathrm{cm})$

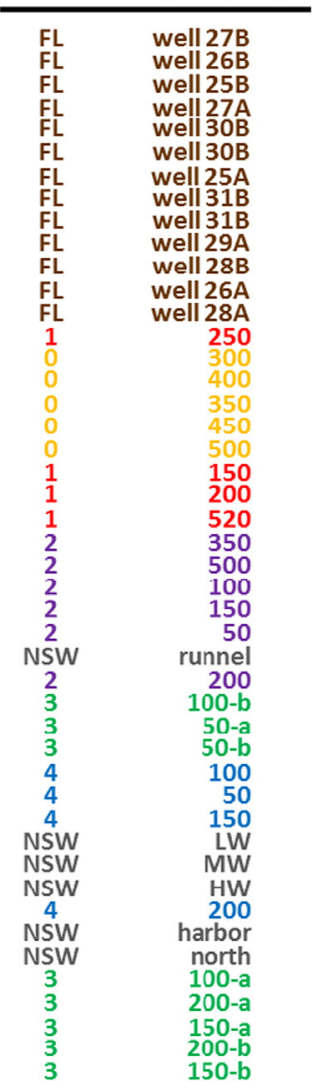

Fig. 8. Cluster analysis (Bray-Curtis) of presence and abundance distribution of all molecular masses detected in DOM from pore water, seawater and the island's freshwater lens. Freshwater lens samples were obtained at seven locations labeled 25 31, as depicted in Röper et al. (2012), from shallow (A) and deep (B) observation wells. The molecular DOM composition of waters from the freshwater lens (FL) is different from the molecular composition of pore water DOM (sites 0-4). Pore water DOM is more similar to North Sea water (NSW) DOM. North Sea water was sampled close to the beach (north, low water (LW), mean water (MW), and high water (HW)), in the beach runnel, and in the harbor of Spiekeroog Island. The molecular composition of pore water DOM extracted at sites 0 and 1 cluster together as well as that at sites 3 and 4 , indicating specific DOM compositions. The color scheme of the pore water sampling sites is the same as in Fig. 7.

in the island's freshwater lens (Fig. 8). The characteristics of colored dissolved organic matter (CDOM), which describe the DOM origin as well, once again support the finding that pore water samples can be mainly traced back to marine sources, especially for sites 2 to 4 . The spectral slope $\mathrm{S}_{\mathrm{CDOM}(275-295 \mathrm{~nm})}$ is above $0.014 \mathrm{~nm}^{-1}$ and the slope ratio against $\mathrm{S}_{\mathrm{CDOM}(350-400 \mathrm{~nm})}$ is above 1.0, indicating a marine source (Helms et al., 2008), except for the sample of lowest salinity at site 3. Furthermore, the absorption $\mathrm{a}_{\mathrm{CDOM}(275 \mathrm{~nm})}$ increases towards the marine dominated sites, indicating again higher amounts of marine than terrestrial CDOM. Only at sites 0 and 1 some terrestrial influence on the DOM composition is shown by lower slopes $\mathrm{S}_{\mathrm{CDOM}(275-295 \mathrm{~nm})}$ and lower slope ratios. In summary, the DOM in both saline and brackish pore water is predominantly of marine origin due to regular seawater infiltration.

Cluster analysis additionally indicates differences in molecular DOM composition at sites 0 and 1 compared to sites 3 and 4 (Fig. 8). The DOM composition at site 2 either clusters with the duneward or the seaward sites, which might be a consequence of changing redox conditions (Jaffé et al., 2008; Riedel et al., 2013). For example, Seidel et al. (2015) showed that the DOM composition at a nearby beach site is influenced by complex biotic and abiotic DOM processing apart from conservative mixing of marine/terrestrial endmembers. They proposed, among other processes, abiotic removal of aromatic, biorefractory compounds, e.g., via flocculation and adsorption to precipitating metal oxides.

\subsection{Pore water origin and redox state control nutrient and metal cycling}

Redox conditions can be categorized into oxic diagenesis $\left(\mathrm{O}_{2}\right.$ reduction), suboxic diagenesis $\left(\mathrm{NO}_{3}^{-}, \mathrm{Mn}\right.$ and Fe reduction) and anoxic diagenesis $\left(\mathrm{SO}_{4}^{2-}\right.$ reduction and methanogenesis) (Froelich et al., 1979). Along the studied beach transect, the redox gradient ranges from completely oxic conditions down to deep sediment layers at the landward sites (sites 0 and 1 ) to oxic only at the surface and anoxic deeper in the sediments at the three seaward sites (Fig. 4).

\subsubsection{Oxic conditions control biogeochemistry at sites 0 and 1}

Sites 0 and 1 , which are only irregularly flooded by seawater, e.g., during storm surges or exceptional high tide levels, exhibit oxic conditions as reflected by high $\mathrm{NO}_{\mathrm{x}}^{-}$concentrations and $\mathrm{O}_{2}$ saturation (Fig. 4, for $\mathrm{O}_{2}$ concentrations in $\mu \mathrm{M}$ see Table $\mathrm{S} 2$ in the supporting information). Lowest measured $\mathrm{Ce}$ (negative $\mathrm{Ce}$-anomalies) and Nd concentrations (Fig. 4) further support the oxic character at these sites, as they indicate Ce removal upon its oxidation to insoluble $\mathrm{Ce}(\mathrm{IV})$ and Nd adsorption onto particles (Elderfield, 1988).

The high $\mathrm{NO}_{\mathrm{x}}^{-}$concentrations up to $260 \mu \mathrm{M}$ do not originate from fertilizers or sewage transported to the beach via groundwater flow because the study site is located in an environmentally protected area, where agriculture and fossil fuel traffic are absent. This is in contrast to several other subterranean estuaries where fertilizers and sewage represent an important nitrogen source (Andersen et al., 2007; Kroeger and Charette, 2008; Wong et al., 2014). Instead, the high $\mathrm{NO}_{\mathrm{x}}^{-}$ concentrations may originate either from seawater or rainwater, or from biogeochemical reactions occurring on site. Seawater infiltration can, however, not be regarded as major inorganic $\mathrm{N}$ source because seawater concentrations are distinctly lower than those found at sites 0 and 1 (9 $\mu \mathrm{M}$ in May 2014). Instead, rainwater is likely an important source because the average $\mathrm{N}$ concentration in rainwater of neighboring islands (Langeoog and Norderney) from monthly measurements over a two year period amounts to $155 \mu \mathrm{M}\left(85 \mu \mathrm{M} \mathrm{NH} \mathrm{N}_{4}^{+}, 70 \mu \mathrm{M} \mathrm{NO}-\right.$ ) (Armbrüster, 2002). Due to highly permeable dune/beach sediments and only scarce dune vegetation, high $\mathrm{N}$ amounts can reach deeper sediment layers. Assuming that pore water at site 0 is simply a mix of rainwater and seawater, $43-67 \%$ of the total inorganic N measured in the pore water can be explained by conservative mixing. Even with a maximum seasonal seawater inorganic $\mathrm{N}$ concentration of $50 \mu \mathrm{M}$ (Reckhardt et al., 2015), this proportion only amounts to 47-75\%. Consequently, 25-57\% (seasonal differences in seawater inorganic $\mathrm{N}$ are considered by giving this range) of the inorganic $\mathrm{N}$ is produced on-site, for example by organic matter degradation. High $\mathrm{O}_{2}$ availability favors $\mathrm{NH}_{4}^{+}$oxidation to $\mathrm{NO}_{\mathrm{x}}^{-}$, which accumulates in the pore water. This conclusion is further supported by the finding that the potential for ammonia oxidation (the first step of nitrification) is shown by DGGE analysis of genes for ammonia oxidation (amoA) of both betaproteobacteria and thaumarchaeota. Both groups are present at all sites and depths and especially the ammonia-oxidizing archaea exhibit the highest diversity in the deeper sediment zones of sites 0,1 , and 2 .

\subsubsection{Changing redox conditions control biogeochemistry at site 2}

At or close to site 2, the redox conditions change from oxic to suboxic in deeper sediment horizons. $\mathrm{O}_{2}$ saturation decreases with depth and reaches zero at about $2 \mathrm{~m}$. Rate measurements using surface sediments from 0 to $10 \mathrm{~cm}$ depth show high potential $\mathrm{O}_{2}$ consumption rates of $44 \mu \mathrm{M} \mathrm{h}^{-1}$ indicating that processes such as organic matter turnover and nitrification occur rapidly in the upper layer. Integrating the volumetric rate down to the $\mathrm{O}_{2}$ penetration depth results in an $\mathrm{O}_{2}$ flux of 
$84 \mathrm{mmol} \mathrm{m}{ }^{-2} \mathrm{~h}^{-1}$, which is even higher than the rate determined for comparable shallow subtidal or intertidal sands (Rusch et al., 2006; Werner et al., 2006). The presence of $\mathrm{NO}_{2}^{-}$at site 2 is also indicative of changing redox conditions because it is either released when $\mathrm{NH}_{4}^{+}$is oxidized via nitrification when encountering aerobic conditions (Kowalchuk et al., 1997) or when $\mathrm{NO}_{3}^{-}$is transformed to $\mathrm{N}_{2}$ via denitrification under anaerobic conditions (Evrard et al., 2013; Slomp and Van Cappellen, 2004).

\subsubsection{Anoxic conditions control biogeochemistry at sites 3 and 4 below an oxycline of some centimeters depth}

The oxycline stretches only across a few centimeters at sites $3 / 4$ and potential $\mathrm{O}_{2}$ consumption rates are three times higher compared to site 2 . This suggests that biogeochemical processes such as $\mathrm{OM}$ degradation and $\mathrm{NH}_{4}^{+}$, Fe or sulfide oxidation occur rapidly in this thin, $\mathrm{O}_{2}$-containing zone. Below the surface sediments, suboxic to anoxic conditions dominate as indicated by increasing concentrations of dissolved $\mathrm{Mn} / \mathrm{Fe}$, probably due to on-site reduction of their particulate phases. The intrusion of fresh/brackish waters from below is an unlikely Mn and Fe source because of their low concentrations in the island's freshwater lens $(<3$ and $16 \mu \mathrm{M}$, respectively, Reckhardt et al., 2015). The classification of the deeper pore waters of sites $3 / 4$ as mainly anoxic is supported by the absence of a negative Ce-anomaly and the increased $\mathrm{Nd}$ concentrations (Fig. 4).

Although anaerobic OM degradation via $\mathrm{SO}_{4}^{2-}$ reduction is not directly shown by our $\mathrm{SO}_{4}^{2-}$ and sulfide measurements, the grayish color of the sediments indicates $\mathrm{SO}_{4}^{2-}$ reduction and sulfide formation leading to the formation of Fe sulfides. Furthermore, changes in the $\mathrm{O}$ isotope composition of the pore water $\mathrm{SO}_{4}^{2-}$ indicate that microbial conversion of $\mathrm{SO}_{4}^{2-}$ must have occurred and sulfide reoxidation is likely an important part of sulfur cycling (Reckhardt et al., 2017). The relative importance of $\mathrm{Mn}, \mathrm{Fe}$, and $\mathrm{SO}_{4}^{2-}$ reduction can, however, not be estimated by our data set because of missing rate measurements. Snyder et al. (2004) showed, for example, that Fe reduction accounts for most of OM degradation at the salinity transitions of an island freshwater lens of Sapelo Island, Georgia, with $\mathrm{SO}_{4}^{2-}$ reduction occurring simultaneously. They concluded that metal reducing bacteria can co-occur with $\mathrm{SO}_{4}^{2-}$ reducing bacteria even at high $\mathrm{SO}_{4}^{2-}$ concentrations if $\mathrm{O}_{2}$ is episodically re-introduced and a dynamic cycle between dissolved $\mathrm{Fe}$ and Fe oxides is maintained.

\subsubsection{Summary biogeochemical zones}

Different biogeochemical zones can be identified in the Spiekeroog beach system (Fig. 9). At sites 0 and 1, oxic conditions and aerobic organic matter degradation dominate. Site 2 , which is located close to the mean high water level (MHWL), exhibits oxic to suboxic conditions and the biogeochemical zones aerobic degradation, nitrification, and denitrification can be identified. In contrast, at sites 3 and 4 the oxic sediment layer stretches only some centimeters, whereas below indications of anoxic conditions and reduction of particulate $\mathrm{Mn} / \mathrm{Fe}$ and $\mathrm{SO}_{4}^{2-}$ are found.

The biogeochemical zones, in turn, are related to OM and nutrient availability as well as pore water residence time. For example, the freshwater diluting the seawater close to the dunes is older (up to 2 years) than the saline water circulating through the USP (some months), where the recharge is higher (Fig. 3). Consequently, residence time does not serve as an explanation for oxic redox conditions in brackish water near the dunes and decreasing oxygen concentrations within the USP (Fig. 4). Here, OM availability may determine redox conditions, either by the amount being introduced or by the lability of the available OM. At our study site, the mainly marine OM origin suggests that the $\mathrm{OM}$ amount is of higher importance for controlling redox conditions than the lability. Close to the low-water line, however, older pore water from greater depth reaches shallow sediments (Fig. 3). Consequently, DOC accumulation and $\mathrm{Mn} / \mathrm{Fe} / \mathrm{SO}_{4}^{2-}$ reducing conditions may be mainly a function of residence time. Similarly, the importance of redox conditions and pore water residence time for controlling oxygen and nutrient concentrations were identified previously for other systems affected by submarine groundwater discharge (Charbonnier et al., 2016; Santos et al., 2008; Slomp and Van Cappellen, 2004).

Previous studies further showed that saltwater-freshwater interfaces may be reaction hotspots (Charette and Sholkovitz, 2002; Roy et al., 2010; Spiteri et al., 2008a). This is not supported by our data. Redox conditions are oxic along the saltwater-freshwater transition zone. Decreases in pore water nutrient concentrations $\left(\mathrm{NO}_{\mathrm{x}}^{-}\right.$, alkalinity) are only due to dilution with seawater of lower nutrient concentrations.

\subsection{Biogeochemical zones influence microbial community patterns}

In our study area, salinity and redox conditions as well as DOM availability vary considerably (Figs. 4,8). The diversity of bacteria and archaea, analyzed as 16S rRNA genes and functional genes for aerobic

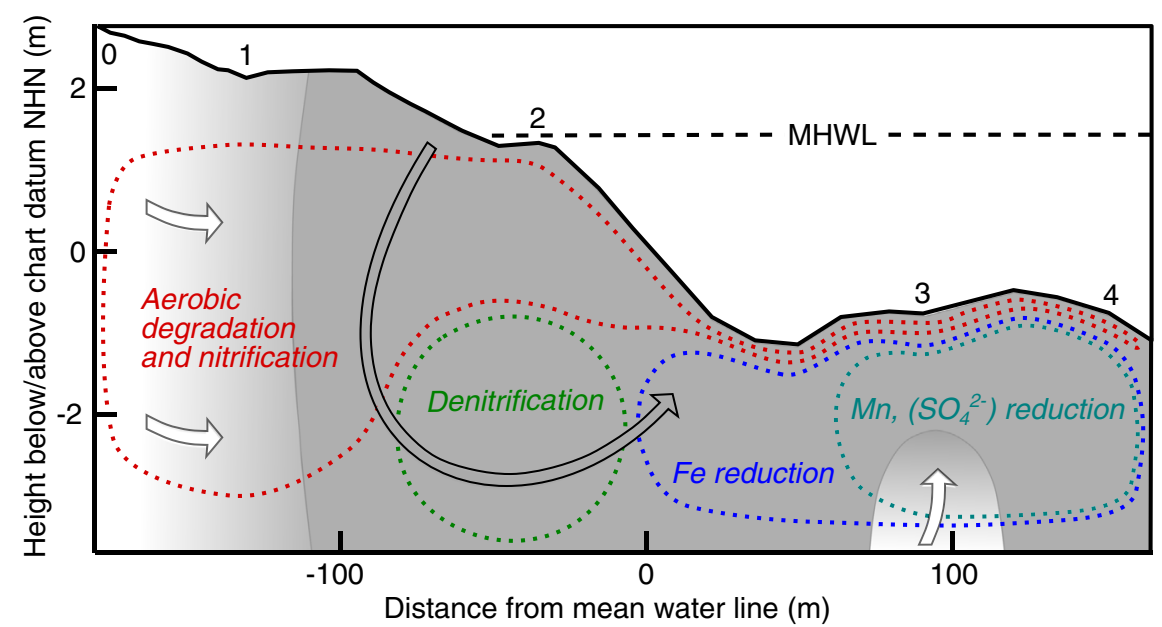

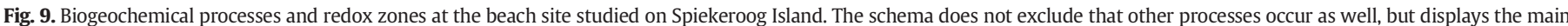

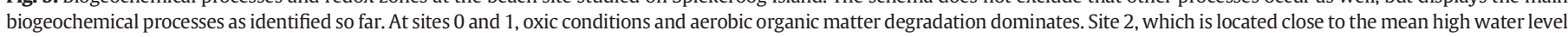

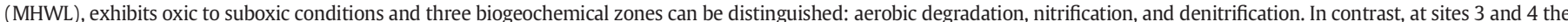

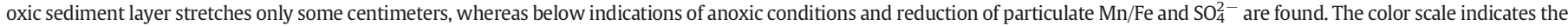

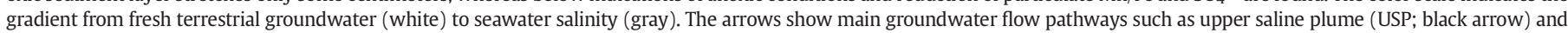
terrestrial freshwater input from the island's freshwater lens and freshwater discharge tube (white arrows). 
ammonia oxidation, $\mathrm{SO}_{4}^{2-}$ reduction and sulfide oxidation, is apparently influenced by these variations in environmental settings (Figs. 6, S3). The clustering of landward and seaward sites, independent on the genes analyzed, indicates that the microbial community was structured by the presence/absence of $\mathrm{O}_{2}$ and the salinity. At the seaward sites, redox conditions may be the main driving force for changing diversity, where the dominant metabolic pathways ( $\mathrm{Mn}, \mathrm{Fe}, \mathrm{SO}_{4}^{2-}$ reduction) vary with depths and between sites. Additionally, the non-specific clustering of the different sediment layers of site 2 may indicate that environmental conditions fluctuate with time. We suggest that changes in the redox environment, which can occur at this site due to short pore water residence times and saturation/desaturation cycles in surface sediments (Jansen et al., 2009; Wilson and Gardner, 2006), are the main driver for the microbial community structures.

Interestingly, the same clustering as of microbial communities is found for the molecular DOM composition, with site 0 and 1 as well as 3 and 4 clustering together while site 2 is in between (Figs. 7, 8). From our data, we cannot infer any causal relationships of DOM and microbial community composition. It is possible that different microbial communities influence the DOM composition in a different way, and vice versa. However, it is more likely that the observed co-variance of DOM and microbial communities reflects prevailing environmental conditions, e.g., salinity and/or redox state.

\subsection{Pore water discharge influences phytobenthos and nearshore waters}

According to the hydrological model, the seawater flux through the USP is on average $2.8 \mathrm{~m}^{3}$ per day and meter of shoreline. This seawater flux is in the same order of magnitude as the fluxes determined by Hays and Ullman (2007) and Mulligan and Charette (2006) for sandy microtidal settings. In contrast, Anschutz et al. (2009) report a groundwater flux about one order of magnitude higher for a macrotidal sandy environment. At our study site, the ridge sediments further discharge 0.5 and $1.0 \mathrm{~m}^{3}$ per day and meter of shoreline to the runnel and the seaside, respectively.

We assume that the pore water concentrations measured at the shallowest sampling depth $(0.5 \mathrm{mbss})$ of the site located $50 \mathrm{~m}$ seaward of site 2 are representative for the discharge region of the USP. To calculate the nutrient flux from the ridge towards the runnel, we used concentrations of site $3(0.5 \mathrm{mbss})$. For discharge from the ridge towards the seaside the average concentrations of site 4 and the site located some meters seaward ( $0.5 \mathrm{mbss})$ were considered. Using these concentrations (Fig. 4) and seawater endmember concentrations of $0.4 \mu \mathrm{M}$ $\mathrm{NH}_{4}^{+}, 0.3 \mu \mathrm{M} \mathrm{PO}_{4}^{3-}$, and $3 \mu \mathrm{M} \mathrm{Si}(\mathrm{OH})_{4}$, as measured in May 2014, calculated net nutrient fluxes of saline beach pore water to adjacent seawater per day and meter of shore line are $103 \mathrm{mmol} \mathrm{NH}_{4}^{+}, 49 \mathrm{mmol} \mathrm{PO}_{4}^{3-}$, and $304 \mathrm{mmol} \mathrm{Si}(\mathrm{OH})_{4}$.

In contrast to the seawater flux through USP and ridge sediments, the freshwater flux is lower, with $0.75 \mathrm{~m}^{3}$ per day and meter of shoreline. We used average nutrient concentrations of 14 samples of the freshwater lens from depths between 6 and 43 mbsl to define freshwater endmembers ( $19 \mu \mathrm{M} \mathrm{NH}_{4}^{+}, 7.4 \mu \mathrm{M} \mathrm{PO}_{4}^{3-}$, and $361 \mu \mathrm{M}$ $\left.\mathrm{Si}(\mathrm{OH})_{4}\right)$. Including freshwater and seawater flux, total nutrient discharge per day and meter shore line amounts to $117 \mathrm{mmol} \mathrm{NH}_{4}^{+}$, $55 \mathrm{mmol} \mathrm{PO}_{4}^{3-}$, and $575 \mathrm{mmol} \mathrm{Si}(\mathrm{OH})_{4}$. We used $\mathrm{NH}_{4}^{+}$, not $\mathrm{NO}_{\mathrm{x}}$, for these calculations, because $\mathrm{NH}_{4}^{+}$is the $\mathrm{N}$ species present in the subto anoxic discharge region of the beach and in the freshwater lens samples.

Nutrient efflux of beach sediments can significantly sustain productive benthic communities that inhabit the seepage zone (Hays and Ullman, 2007; Ullman et al., 2003). In our study area, increasing normalized Chl $a$, POC, and POP concentrations in the seepage zone, especially the beach runnel (Phytobenthos site 6, Fig. 6), indicate a stimulation of the phytobenthos growth by groundwater controlled nutrient effluxes.
4.6. Nutrient discharge from tidal flat margins is more important than efflux from barrier island beaches for nearshore North Sea waters

Overall, this first SGD and nutrient export estimation for the Spiekeroog beach system indicates that groundwater discharge is an important pathway to supply nutrients to nearshore waters of the southern North Sea. However, the present study so far does not support the hypothesis that beach systems may be of greater importance for nutrient recycling and efflux than sandy tidal flat sediments. The latter were shown to be of great importance for carbon, nutrient, and trace metal cycles in the large tidal flat area called Wadden Sea stretching from the Netherlands to Denmark, and the frequent water exchange between tidal flat areas and the North Sea transport carbon, nutrient, and trace metals to coastal waters of the North Sea (e.g. Beck et al., 2008; Billerbeck et al., 2006; Grunwald et al., 2010; Marchant et al., 2014; Moore et al., 2011; Riedel et al., 2011; Røy et al., 2008; Santos et al., 2015). Pore water discharge rates calculated for nearby sandy Wadden Sea sediments vary depending on the method applied and the sediment depth considered (Billerbeck et al., 2006; Moore et al., 2011; Riedel et al., 2010), among which the method most comparable to the model approach applied in our study resulted in lower flux rates $\left(0.97 \mathrm{~m}^{-3}\right.$ per tide and meter of shoreline, which equals $\sim 2 \mathrm{~m}^{-3}$ per day and meter of shoreline; Riedel et al., 2010) compared to our study. Due to the high nutrient enrichment in the tidal flat pore waters compared to Spiekeroog beach sediments (Reckhardt et al., 2015), the nutrient efflux from these sediments can, however, be higher compared to the beach site. For example, the $\mathrm{NH}_{4}^{+}$efflux was estimated to reach up to $430 \mathrm{mmol}$ per tide and meter of shoreline (Riedel et al., 2011), which is about seven times higher than the sum of all $\mathrm{NH}_{4}^{+}$discharge pathways from the beach sediments.

To estimate the importance of beaches in terms of nutrient contribution to the North Sea, the nutrient efflux determined at Spiekeroog beach was extrapolated to the entire East-Frisian barrier island chain from Borkum to Wangerooge (without Kachelotplate and Memmert). This estimation is based on the assumption that the nutrient efflux determined in our study is representative for the beach zones of the barrier islands, which are facing the open North Sea and are in contact with a freshwater lens. This zone was estimated to be $56 \mathrm{~km}$ long. Based on nutrient discharge rates described previously, the total fluxes (including seawater and freshwater fluxes) from beaches to adjacent nearshore waters are $24 * 10^{5}, 11 * 10^{5}$, and $118 * 10^{5} \mathrm{~mol} \mathrm{a}^{-1}$ for $\mathrm{NH}_{4}^{+}, \mathrm{PO}_{4}^{3-}$, and $\mathrm{Si}(\mathrm{OH})_{4}$, respectively. Similarly, the nutrient export of the Spiekeroog backbarrier tidal flats was extrapolated to the entire Wadden Sea (from the Netherlands to Denmark) resulting in an export of $70 * 10^{6}$ and $30 * 10^{8} \mathrm{~mol} \mathrm{a}^{-1}$ for $\mathrm{PO}_{4}^{3-}$, and $\mathrm{Si}(\mathrm{OH})_{4}$, respectively, from the backbarrier areas to the southern North Sea (Grunwald et al., 2010). Although the extrapolations do not consider the same areas (East-Frisian versus total Wadden Sea), a first comparison shows that the beach zone seems to export less $(<10 \%)$ phosphate and silicate than the backbarrier tidal flat areas.

\section{Perspectives}

The studies carried out in the beach system of Spiekeroog Island showed that in mesotidal settings sediments are continuously flushed by sea water down to several meters depth in the zone of the USP (Fig. 3). Furthermore, sea water may circulate through ridge sediments. Redox conditions and pore water residence time control biogeochemical zones (Figs. 4, 9). Furthermore, biogeochemistry is influenced by OM availability, especially in the freshwater-dominated part of the beach, which is only irregularly flooded by sea water and fresh OM input is limited.

In summary, the beach consists of three zones: 1) the freshwaterdominated, oxic zone, which is located behind a backshore berm and only flooded irregularly, and which exhibits limited OM availability, 2) the seawater-influenced, oxic to suboxic USP zone where pore water 
circulation may lead to regular oxygen, nutrient, and OM availability changes, and 3) the seawater-influenced, mainly anoxic zone in the ridge sediments. This zonation influences the microbial community patterns as reflected in the clustering of landward and seaward sites (Fig. 7).

Pore water discharge of Spiekeroog beach sediments supplies nutrients to nearshore waters. Nutrient fluxes of saline pore water are the major $\mathrm{N}$ and $\mathrm{P}$ source to nearshore waters, whereas fresh and saline pore waters transport equal amounts of $\mathrm{Si}$. The importance of Spiekeroog beach sediments in supplying nutrients to nearshore waters is, however, reduced due to its special geographical location next to the large tidal flat area called Wadden Sea. In this area, similar pore water discharge rates, but much higher nutrient concentrations lead to higher nutrient effluxes compared to the beach sediments.

An essential next step while studying the beach system of Spiekeroog Island, but also other systems worldwide, will be to extend the knowledge to greater sediment depths, at least up to where the freshwater discharge tube is intersected and the underlying saltwater wedge is met. This will lead to a refined groundwater flow model, to a better understanding of the key processes in biogeochemistry, of the role of organisms for OM degradation, and of the fluxes at the sediment-water interface. To date, most studies on hydrological and biogeochemical processes in subterranean estuaries of beach systems were carried out in microtidal and/or low-energy environments such as semi-protected bay situations (Charette and Sholkovitz, 2006; Heiss and Michael, 2014; McAllister et al., 2015; Santos et al., 2008; Ullman et al., 2003). Therefore, a maximum sampling depth of about $5 \mathrm{~m}$ was sufficient to resolve the USP at these study sites. A mesotidal beach system was, for example, sampled by Robinson et al. (2006). Their model results show an USP stretching to about $8 \mathrm{~m}$ depth, but their measurements of the salinity distribution in the subterranean estuary covered only the upper $2 \mathrm{~m}$ of the sediments. A meso- to macrotidal setting was studied at the western coast of France by Anschutz et al. (2009, 2016), Buquet et al. (2016), and Charbonnier et al. (2013). However, their biogeochemical sampling strategy did not involve spatial distribution patterns down to several meters depths, but focused on pore water samples of the top of the water-saturated zone. Consequently, it will be a technical challenge in future studies to monitor processes at mesoand macrotidal settings with USPs extending down to depths of about $25 \mathrm{~m}$ as indicated by the hydrological model in our study.

Furthermore, only a few comprehensive reactive transport modeling studies have been conducted to date in the context of submarine groundwater discharge (Cardenas et al., 2008; Porubsky et al., 2011; Spiteri et al., 2008a, 2008b). However, reactive transport modeling will allow to gain an in-depth understanding of biogeochemical processes and will help to verify the conclusions drawn using, for example, pore water concentrations or biogeochemical rate measurements alone. Reactive transport modeling will further help to verify pore water discharge rates estimated using seepage meters or radium isotopes. This will be an essential step to address the question how the pore water discharge of beach systems influences biogeochemistry in nearshore waters.

\section{Conclusions}

The offshore exposed beach of Spiekeroog Island displays a typical beach at the transition from a dissipative winter morphology to a reflective summer situation. The cross-shore beach transect exhibits oxic conditions within the duneward freshwater influenced section, changing redox conditions with depth close to the mean high water level, and the dominance of $\mathrm{Mn} / \mathrm{Fe}$ and $\mathrm{SO}_{4}^{2-}$ reduction below a thin oxycline of some centimeters in the seaward part of the transect. The assumption that saltwater-freshwater interfaces are reaction hotspots is not supported by our data. Instead, biogeochemical processes are influenced by the mixing of water masses of different origin (freshwater/seawater) as well as by changing redox conditions within these two water types.
The DOM in the studied pore waters down to $5 \mathrm{~m}$ depth is mainly of marine origin as indicated by both CDOM and molecular DOM composition analyses. Only in the duneward section, CDOM parameters reflect some influence of terrestrial OM. Microbial community patterns seem to be mainly influenced by changing redox conditions and to a lesser extent by salinity variations.

Modeled pore water discharge rates are similar to those proposed for other micro- and mesotidal beach settings. Nutrient effluxes seem to stimulate growth of microphytobenthos on beach sediments of the seepage zone. The beach site shows higher pore water discharge rates compared with a nearby sandy backbarrier tidal flat margin. However, lower nutrient concentrations in the pore waters at the beach site indicate that the backbarrier tidal flat area might be of greater importance for supplying recycled nutrients to nearshore waters of the southern North Sea than the beach systems of the barrier islands.

\section{Acknowledgements}

We thank the Wadden Sea National Park Administration of Lower Saxony for the permission to study the beach site on Spiekeroog Island. We would also like to thank S. Fock and C. Winkelmann from the Research Center Wittbülten on Spiekeroog. Furthermore, we thank $\mathrm{H}$. Nicolai, G. Behrens, and T. Jansen for the boat transfer and their assistance during planning the sampling campaign as well as their technical support during sampling. The crew of the FK Senckenberg is gratefully acknowledged for coring in the shallow shoreface. Thanks to the staff of the Lower Saxony Water Management, Coastal Defense and Nature Conservation Agency for transporting the sampling equipment to the study site. We thank S. Ahmerkamp, C. Ehlert, J. Feldkamp, M. Friebe, K. Klaproth, C. Lehners, F. Meyerjürgens, N. Rüssmeier, T. Riedel, I. Ulber, D. Voß, and M. Wilsenack for assistance during sampling and laboratory support. The students J. Ahrens, J. Bessler, W. Preuss, and I. Schueller are thanked for their support during sampling, labwork, and data interpretation. The sampling campaign was financially supported by the Institute for Chemistry and Biology of the Marine Environment, University of Oldenburg, by Senckenberg am Meer, Wilhelmshaven, and by the Max Planck Institute for Marine Microbiology, Bremen.

\section{Appendix A. Supplementary data}

Supplementary data to this article can be found online at http://dx. doi.org/10.1016/j.marchem.2017.01.001.

\section{References}

Andersen, M.S., Baron, L., Gudbjerg, J., Gregersen, J., Chapellier, D., Jakobsen, R., Postma, D. 2007. Discharge of nitrate-containing groundwater into a coastal marine environment. J. Hydrol. 336:98-114. http://dx.doi.org/10.1016/j.jhydrol.2006.12.023.

Anschutz, P., Charbonnier, C., Deborde, J., Deirmendjian, L., Poirier, D., Mouret, A., Buquet D., Lecroart, P., 2016. Terrestrial groundwater and nutrient discharge along the 240 km-long Aquitanian coast. Mar. Chem. 185:38-47. http://dx.doi.org/10.1016/j. marchem.2016.04.002.

Anschutz, P., Smith, T., Mouret, A., Deborde, J., Bujan, S., Poirier, D., Lecroart, P., 2009. Tida sands as biogeochemical reactors. Estuar. Coast. Shelf Sci. 84:84-90. http://dx.doi.org/ 10.1016/j.ecss.2009.06.015

Anwar, N., Robinson, C., Barry, D.A., 2014. Influence of tides and waves on the fate of nutrients in a nearshore aquifer: numerical simulations. Adv. Water Resour. 73: 203-213. http://dx.doi.org/10.1016/j.advwatres.2014.08.015.

Armbrüster, N., 2002. Wasser- und Nährstoffhaushalt grundwasserabhängiger Pflanzengesellschaften der feuchten Dünentäler auf den Ostfriesischen Inseln. Thesis. Univ. Oldenbg., pp. 1-157.

Bakhtyar, R., Brovelli, A., Barry, D.A., Li, L., 2011. Wave-induced water table fluctuations, sediment transport and beach profile change: modeling and comparison with large-scale laboratory experiments. Coast. Eng. 58:103-118. http://dx.doi.org/10 1016/j.coastaleng.2010.08.004.

Beck, M., Brumsack, H.-J., 2012. Biogeochemical cycles in sediment and water column of the Wadden Sea: the example Spiekeroog Island in a regional context. Ocean Coast. Manag. 68, 102-113.

Beck, M., Dellwig, O., Schnetger, B., Brumsack, H.-J., 2008. Cycling of trace metals (Mn, Fe, $\mathrm{Mo}, \mathrm{U}, \mathrm{V}, \mathrm{Cr}$ ) in deep pore waters of intertidal flat sediments. Geochim. Cosmochim. Acta 72:2822-2840. http://dx.doi.org/10.1016/j.gca.2008.04.013. 
Billerbeck, M., Werner, U., Polerecky, L., Walpersdorf, E., de Beer, D., Huettel, M., 2006. Surficial and deep pore water circulation governs spatial and temporal scales of nutrient recycling in intertidal sand flat sediment. Mar. Ecol. Prog. Ser. 326, 61-76.

Buquet, D., Sirieix, C., Anschutz, P., Malaurent, P., Charbonnier, C., Naessens, F., Bujan, S. Lecroart, P., 2016. Shape of the shallow aquifer at the fresh water - sea water interface on a high-energy sandy beach. Estuar. Coast. Shelf Sci. 179, 79-89.

Butt, T., Russell, P., Turner, I., 2001. The influence of swash infiltration-exfiltration on beach face sediment transport: onshore or offshore? Coast. Eng. 42:35-52. http:// dx.doi.org/10.1016/S0378-3839(00)00046-6.

Cardenas, M.B., Cook, P.L.M., Jiang, H., Traykovski, P., 2008. Constraining denitrification in permeable wave-influenced marine sediment using linked hydrodynamic and biogeochemical modeling. Earth Planet. Sci. Lett. 275:127-137. http://dx.doi.org/10. 1016/j.epsl.2008.08.016.

Charbonnier, C., Anschutz, P., Deflandre, B., Bujan, S., Lecroart, P., 2016. Measuring pore water oxygen of a high-energy beach using buried probes. Estuar. Coast. Shelf Sci. 179:66-78. http://dx.doi.org/10.1016/j.ecss.2015.12.004.

Charbonnier, C., Anschutz, P., Poirier, D., Bujan, S., Lecroart, P., 2013. Aerobic respiration in a high-energy sandy beach. Mar. Chem. 155:10-21. http://dx.doi.org/10.1016/j. marchem.2013.05.003.

Charette, M.A., Sholkovitz, E.R., 2002. Oxidative precipitation of groundwater-derived ferrous iron in the subterranean estuary of a coastal bay. Geophys. Res. Abstr. 29, 1-4

Charette, M.A., Allen, M.C., 2006. Precision ground water sampling in coastal aquifers using a direct-push, shielded-screen well-point system. Gr. Water Monit. Remediat. 26:87-93. http://dx.doi.org/10.1111/j.1745-6592.2006.00076.x.

Charette, M.A., Sholkovitz, E.R., 2006. Trace element cycling in a subterranean estuary: part 2. Geochemistry of the pore water. Geochim. Cosmochim. Acta 70:811-826. http://dx.doi.org/10.1016/j.gca.2005.10.019.

Chipman, L., Podgorski, D., Green, S., Kostka, J., Cooper, W., Huettel, M., 2010. Decomposition of plankton-derived dissolved organic matter in permeable coastal sediments. Limnol. Oceanogr. 55:857-871. http://dx.doi.org/10.4319/lo.2009.55.2.0857.

Cline, J., 1969. Spectrophotometric determination of hydrogen sulfide in natural waters. Limnol. Oceanogr. 14:454-458. http://dx.doi.org/10.4319/lo.1969.14.3.0454.

Dittmar, T., Koch, B., Hertkorn, N., Kattner, G., 2008. A simple and efficient method for the solid-phase extraction of dissolved organic matter (SPE-DOM) from seawater. Limnol. Oceanogr. 6, 230-235.

Dobrynin, M., Gayer, G., Pleskachevsky, A., Guenther, H., 2010. Effect of waves and currents on the dynamics and seasonal variations of suspended particulate matter in the North Sea. J. Mar. Syst. 82, 1-20.

Dugan, J.E., Defeo, O., Jaramillo, E., Jones, A.R., Lastra, M., Nel, R., Peterson, C.E., Scapini, F., Schlacher, T., Schoeman, D.S., 2010. Give beach ecosystems their day in the sun. Science $329,1146$.

Ehrenhauss, S., Witte, U., Bühring, S.I., Huettel, M., 2004. Effect of advective pore water transport on distribution and degradadtion of diatoms in permeable North Sea sediments. Mar. Ecol. Prog. Ser. 271:99-111. http://dx.doi.org/10.3354/meps271099.

Elderfield, H., 1988. The oceanic chemistry of the rare-earth elements. Philos. Trans. R. Soc. London. Ser. A, Math. Phys. Sci. Tracers Ocean 325, 105-126.

Evrard, V., Glud, R.N., Cook, P.L.M., 2013. The kinetics of denitrification in permeable sediments. Biogeochemistry 113:563-572. http://dx.doi.org/10.1007/s10533-012-9789-x.

Forehead, H., Thomson, P., Kendrick, G.A., 2013. Shifts in composition of microbial communities of subtidal sandy sediments maximise retention of nutrients. FEMS Microbiol. Ecol. 83:279-298. http://dx.doi.org/10.1111/j.1574-6941.2012.01472.x

Francis, C.A., Roberts, K.J., Beman, J.M., Santoro, A.E., Oakley, B.B., 2005. Ubiquity and diversity of ammonia-oxidizing archaea in water columns and sediments of the ocean. Proc. Natl. Acad. Sci. U. S. A. 102:14683-14688. http://dx.doi.org/10.1073/ pnas.0506625102.

Froelich, P.N., Klinkhammer, G.P., Bender, M.L., Luedtke, N.A., Heath, G.R., Cullen, D. Dauphin, P., Hammond, D., Hartman, B., Maynard, V., 1979. Early oxidation of organic-matter in pelagic sediments of the Eastern Equatorial Atlantic - suboxic diagenesis. Geochim. Cosmochim. Acta 43, 1075-1090.

Gao, H., Matyka, M., Liu, B., Khalili, A., Kostka, J.E., Collins, G., Jansen, S., Holtappels, M., Jensen, M.M., Badewien, T.H., Beck, M., Grunwald, M., de Beer, D., Lavik, G., Kuypers, M.M.M., 2012 Intensive and extensive nitrogen loss from intertidal permeable sediments of the Wadden Sea. Limnol. Oceanogr. 57:185-198. http://dx.doi.org/10.4319/lo.2012.57.1.0185.

Garaba, S., Voß, D., Zielinski, O., 2014. Physical, bio-optical state and correlations in northwestern european shelf seas. Remote Sens. 6:5042-5066. http://dx.doi.org/10.3390/ rs6065042.

German, C.R., Masuzawa, T., Greaves, M.J., Elderfield, H., Edmond, J.M., 1995. Dissolved rare earth elements in the Southern Ocean: cerium oxidation and the influence of hydrography. Geochim. Cosmochim. Acta 59:1551-1558. http://dx.doi.org/10.1016/ 0016-7037(95)00061-4.

Gibbes, B., Robinson, C., Carey, H., Li, L., Lockington, D., 2008. Tidally driven pore water exchange within offshore intertidal sandbanks: part II numerical simulations. Estuar. Coast. Shelf Sci. 79:121-132. http://dx.doi.org/10.1016/j.ecss.2008.08.021.

Grunwald, M., Dellwig, O., Kohlmeier, C., Kowalski, N., Beck, M., Badewien, T.H., Kotzur, S., Liebezeit, G., Brumsack, H.-J., 2010. Nutrient dynamics in a back barrier tidal basin of the Southern North Sea: time-series, model simulations, and budget estimates. J. Sea Res. 64:199-212. http://dx.doi.org/10.1016/j.seares.2010.02.008.

Haley, B.A., Klinkhammer, G.P., McManus, J., 2004. Rare earth elements in pore waters of marine sediments. Geochim. Cosmochim. Acta 68:1265-1279. http://dx.doi.org/10. 1016/j.gca.2003.09.012.

Hammer, Ø., Harper, D.A.T., Ryan, P.D., 2001. PAST: Paleontological statistics software package for education and data analysis. Palaeontol. Electron. 4 (1) (9 pp.). http:// palaeo-electronica.org/2001_1/past/is.

Harris, L., Nel, R., Smale, M., Schoeman, D., 2011. Swashed away? Storm impacts on sandy beach macrofaunal communities. Estuar. Coast. Shelf Sci. 94:210-221. http://dx.doi. org/10.1016/j.ecss.2011.06.013.
Hathorne, E.C., Haley, B., Stichel, T., Grasse, P., Zieringer, M., Frank, M., 2012. Online preconcentration ICP-MS analysis of rare earth elements in seawater. Geochem. Geophys. Geosyst. 13, Q01020. http://dx.doi.org/10.1029/2011gc003907.

Hays, R.L., Ullman, W.J., 2007. Direct determination of total and fresh groundwater discharge and nutrient loads from a sandy beachface at low tide (Cape Henlopen, Delaware). Limnol. Oceanogr. 52:240-247. http://dx.doi.org/10.4319/lo.2007.52.1.0240.

Heiss, J.W., Michael, H.A., 2014. Saltwater-freshwater mixing dynamics in a sandy beach aquifer over tidal, spring-neap, and seasonal cycles. Water Resour. Res. 50: 6747-6766. http://dx.doi.org/10.1002/2014WR015574.

Heiss, J.W., Ullman, W.J., Michael, H.A., 2014. Swash zone moisture dynamics and unsaturated infiltration in two sandy beach aquifers. Estuar. Coast. Shelf Sci. 143:20-31. http://dx.doi.org/10.1016/j.ecss.2014.03.015.

Hellwig, U., Stock, M., 2014. Dynamic Islands in the Wadden Sea. Wadden Sea Ecosyst. 33, $1-134$.

Helms, J.R., Stubbins, A., Ritchie, J.D., Minor, E.C., Kieber, D.J., Mopper, K., 2008. Absorption spectral slopes and slope ratios as indicators of molecular weight, source, and photobleaching of chromophoric dissolved organic matter. Limnol. Oceanogr. 53: 955-969. http://dx.doi.org/10.4319/lo.2008.53.3.0955.

Hinkel, J., Nicholls, R.J., Tol, R.S.J., Wang, Z.B., Hamilton, J.M., Boot, G., Vafeidis, A.T., McFadden, L., Ganopolski, A., Klein, R.J.T., 2013. A global analysis of erosion of sandy beaches and sea-level rise: an application of DIVA. Glob. Planet. Chang. 111: 150-158. http://dx. doi.org/10.1016/j.gloplacha.2013.09.002.

Hubas, C., Artigas, L.F., Davoult, D., 2007a. Role of the bacterial community in the annual benthic metabolism of two contrasted temperate intertidal sites (Roscoff Aber Bay, France). Mar. Ecol. Prog. Ser. 344:39-48. http://dx.doi.org/10.3354/meps06947.

Hubas, C., Lamy, D., Artigas, L.F., Davoult, D., 2007b. Seasonal variability of intertidal bacterial metabolism and growth efficiency in an exposed sandy beach during low tide. Mar. Biol. 151:41-52. http://dx.doi.org/10.1007/s00227-006-0446-6.

Huettel, M., Berg, P., Kostka, J.E., 2014. Benthic exchange and biogeochemical cycling in permeable sediments. Annu. Rev. Mar. Sci. 6:23-51. http://dx.doi.org/10.1146/ annurev-marine-051413-012706.

Huettel, M., Ziebis, W., Forster, S., Luther III, G.W., 1998. Advective transport affecting metal and nutrient distributions and interfacial fluxes in permeable sediments. Geochim. Cosmochim. Acta 62:613-631. http://dx.doi.org/10.1016/S00167037(97)00371-2.

Ibánhez, J.S.P., Rocha, C., 2014. Effects of recirculation of seawater enriched in inorganic nitrogen on dissolved organic carbon processing in sandy seepage face sediments. Mar. Chem. 166:48-58. http://dx.doi.org/10.1016/j.marchem.2014.09.012.

Jaffé, R., Mcknight, D., Maie, N., Cory, R., Mcdowell, W.H., Campbell, J.L., 2008. Spatial and temporal variations in DOM composition in ecosystems: the importance of long-term monitoring of optical properties. J. Geophys. 113:1-15. http://dx.doi.org/10.1029/ 2008JG000683.

Jansen, S., Walpersdorf, E., Werner, U., Billerbeck, M., Böttcher, M.E., de Beer, D., 2009. Functioning of intertidal flats inferred from temporal and spatial dynamics of $\mathrm{O}_{2}$, $\mathrm{H}_{2} \mathrm{~S}$ and $\mathrm{pH}$ in their surface sediment. Ocean Dyn. 59:317-332. http://dx.doi.org/10. 1007/s10236-009-0179-4.

Kirk, J.T.O., 2011. Light and Photosynthesis in Aquatic Ecosystems. third ed. Cambridge, Cambridge University Press.

Kowalchuk, G.A., Stephen, J.R., De Boer, W., Prosser, J.I., Embley, T.M., Woldendorp, J.W., 1997. Analysis of ammonia-oxidizing bacteria of the beta subdivision of the class Proteobacteria in coastal sand dunes by denaturing gradient gel electrophoresis and sequencing of PCR-amplified $16 \mathrm{~S}$ ribosomal DNA fragments. Appl. Environ. Microbiol. 63:1489-1497. http://dx.doi.org/10.1128/AEM.67.10.4880.

Kroeger, K.D., Charette, M.A., 2008. Nitrogen biogeochemistry of submarine groundwater discharge. Limnol. Oceanogr. 53:1025-1039. http://dx.doi.org/10.4319/lo.2008.53.3. 1025.

Kwon, E.Y., Kim, G., Primeau, F., Moore, W.S., Cho, H.-M., DeVries, T., Sarmiento, J.L., Charette, M.A., Cho, Y.-K., 2014. Global estimate of submarine groundwater discharge based on an observationally constrained radium isotope model. Geophys. Res. Lett. 41:62-68. http://dx.doi.org/10.1002/2014GL061574.Received.

Langevin, C.D., Thorne Jr., D.T., Dausmann, A.M., Sukop, M.C., Weixing, G., 2007. Seawat version 4: a computer program for simulation of multi-species solute and heat transport. Technical Report. U.S. Geol. Surv. Tech. Methods B. 6 (Chapter A22, 39pp).

Loveless, A.M., Oldham, C.E., 2010. Natural attenuation of nitrogen in groundwater discharging through a sandy beach. Biogeochemistry 98:75-87. http://dx.doi.org/ 10.1007/s10533-009-9377-x.

Marchant, H.K., Lavik, G., Holtappels, M., Kuypers, M.M.M., 2014. The fate of nitrate in intertidal permeable sediments. PLoS One 9, e104517.

McAllister, S.M., Barnett, J.M., Heiss, J.W., Findlay, A.J., MacDonald, D.J., Dow, C.L., Luther, G.W., Michael, H.A., Chan, C.S., 2015. Dynamic hydrologic and biogeochemical processes drive microbially enhanced iron and sulfur cycling within the intertidal mixing zone of a beach aquifer. Limnol. Oceanogr. 60:329-345. http://dx.doi.org/10.1111/ lno.10029,

McLachlan, A., Brown, A.C., 2006. The Ecology of Sandy Shores. Acad. Press, Burlington, Massachusetts.

Meyer, B., Kuever, J., 2007. Molecular analysis of the diversity of sulfate-reducing and sulfur-oxidizing prokaryotes in the environment, using aprA as functional marker gene. Appl. Environ. Microbiol. 73:7664-7679. http://dx.doi.org/10.1128/aem.01272-07.

Michael, H.A., Mulligan, A.E., Harvey, C.F., 2005. Seasonal oscillations in water exchange between aquifers and the coastal ocean. Nature 436:1145-1148. http://dx.doi.org/ 10.1038 /nature03935.

Moore, W.S., 1996. Large groundwater inputs to coastal waters revealed by 226Ra enrichments. Nature 380, 612-614.

Moore, W.S., Sarmiento, J.L., Key, R.M., 2008. Submarine groundwater discharge revealed by 228Ra distribution in the upper Atlantic Ocean. Nat. Geosci. 1:309-311. http://dx. doi.org/10.1038/ngeo183. 
Moore, W.S., Beck, M., Riedel, T., Rutgers van der Loeff, M., Dellwig, O., Shaw, T.J., Schnetger, B., Brumsack, H.-J., 2011. Radium-based pore water fluxes of silica, alkalinity, manganese, DOC, and uranium: a decade of studies in the German Wadden Sea. Geochim. Cosmochim. Acta 75:6535-6555. http://dx.doi.org/10.1016/j.gca.2011.08.037.

Mulligan, A.E., Charette, M.A., 2006. Intercomparison of submarine groundwater discharge estimates from a sandy unconfined aquifer. J. Hydrol. 327:411-425. http:// dx.doi.org/10.1016/j.jhydrol.2005.11.056

Mulligan, A.E., Langevin, C., Post, V.E.A., 2011. Tidal boundary conditions in SEAWAT. Ground Water 49:866-879. http://dx.doi.org/10.1111/j.1745-6584.2010.00788.x.

Muyzer, G., Teske, A., Wirsen, C.O., Jannasch, H.W., 1995. Phylogenetic relationships of Thiomicrospira species and their identification in deep-sea hydrothermal vent samples by denaturing gradient gel-electrophoresis of 16S rDNA fragments. Arch. Microbiol. 164:165-172. http://dx.doi.org/10.1007/bf02529967.

Nel, R., Campbell, E.E., Harris, L., Hauser, L., Schoeman, D.S., McLachlan, A., du Preez, D.R., Karien, B., Schlacher, T.A., 2014. The status of sandy beach science: past trends, progress, and possible futures. Estuar. Coast. Shelf Sci. 150, 1-10.

Nicol, G.W., Glover, L.A., Prosser, J.I., 2003. The impact of grassland management on archaeal community structure in upland pasture rhizosphere soil. Environ. Microbiol. $5,152-162$.

Paerl, H.W., 1997. Coastal eutrophication and harmful algal blooms: importance of atmospheric deposition and groundwater as new nitrogen and other nutrient sources. Limnol. Oceanogr. 42:1154-1165. http://dx.doi.org/10.4319/lo.1997.42.5_part_2. 1154.

Pahnke, K., van de Flierdt, T., Jones, K.M., Lambelet, M., Hemming, S.R., Goldstein, S.L., 2012. GEOTRACES intercalibration of neodymium isotopes and rare earth element concentrations in seawater and suspended particles. Part 2: systematic tests and baseline profiles. Limnol. Oceanogr. Methods 10:252-269. http://dx.doi.org/10. 4319/lom.2012.10.252.

Porubsky, W.P., Joye, S.B., Moore, W.S., Tuncay, K., Meile, C., 2011. Field measurements and modeling of groundwater flow and biogeochemistry at Moses Hammock, a backbarrier island on the Georgia coast. Biogeochemistry 104:69-90. http://dx.doi. org/10.1007/s10533-010-9484-8.

Post, V.E.A., 2011. A new package for simulating periodic boundary conditions in MODFLOW and SEAWAT. Comput. Geosci. 37:1843-1849. http://dx.doi.org/10. 1016/j.cageo.2011.01.012.

Precht, E., Huettel, M., 2003. Advective pore-water exchange driven by surface gravity waves and its ecological implications. Limnol. Oceanogr. 48:1674-1684. http://dx. doi.org/10.4319/lo.2003.48.4.1674.

Reckhardt, A., Beck, M., Greskowiak, J., Schnetger, B., Böttcher, M., Gehre, M., Brumsack, H.-J., 2017. Cycling of redox-sensitive elements in a sandy subterranean estuary of the southern North Sea. Mar. Chem. Rev. 188, 6-17.

Reckhardt, A., Beck, M., Seidel, M., Riedel, T., Wehrmann, A., Bartholomä, A., Schnetger, B. Dittmar, T., Brumsack, H.-J., 2015. Carbon, nutrient and trace metal cycling in sandy sediments: a comparison of high-energy beaches and backbarrier tidal flats. Estuar. Coast. Shelf Sci. 159, 1-14.

Riedel, T., Lettmann, K., Beck, M., Brumsack, H.-J., 2010. Tidal variations in groundwater storage and associated discharge from an intertidal coastal aquifer. J. Geophys. Res. 115, C04013. http://dx.doi.org/10.1029/2009JC005544.

Riedel, T., Lettmann, K., Schnetger, B., Beck, M., Brumsack, H.-J., 2011. Rates of trace metal and nutrient diagenesis in an intertidal creek bank. Geochim. Cosmochim. Acta 75: 134-147. http://dx.doi.org/10.1016/j.gca.2010.09.040.

Riedel, T., Zak, D., Biester, H., Dittmar, T., 2013. Iron traps terrestrially derived dissolved organic matter at redox interfaces. PNAS 110:10101-10105. http://dx.doi.org/10. 1073/pnas.1221487110.

Robinson, C., Gibbes, B., Li, L., 2006. Driving mechanisms for groundwater flow and salt transport in a subterranean estuary. Geophys. Res. Lett. 33, L03402. http://dx.doi. org/10.1029/2005GL025247.

Robinson, C., Gibbes, B., Carey, H., Li, L., 2007a. Salt-freshwater dynamics in a subterranean estuary over a spring-neap tidal cycle. J. Geophys. Res. Oceans Atmos. 112: 1-15. http://dx.doi.org/10.1029/2006JC003888.

Robinson, C., Li, L., Barry, D.A., 2007b. Effect of tidal forcing on a subterranean estuary. Adv. Water Resour. 30:851-865. http://dx.doi.org/10.1016/j.advwatres.2006.07.006.

Robinson, C., Xin, P., Li, L., Barry, D.A., 2014. Groundwater flow and salt transport in a subterranean estuary driven by intensified wave conditions. Water Resour. Res. 50: 165-181. http://dx.doi.org/10.1002/2013WR013813.

Rodellas, V., Garcia-Orellana, J., Tovar-Sánchez, A., Basterretxea, G., López-Garcia, J.M., Sánchez-Quiles, D., Garcia-Solsona, E., Masqué, P., 2014. Submarine groundwater discharge as a source of nutrients and trace metals in a Mediterranean bay (Palma Beach, Balearic Islands). Mar. Chem. 160:56-66. http://dx.doi.org/10.1016/j. marchem.2014.01.007.

Rodil, I.F., Lastra, M., 2004. Environmental factors affecting benthic macrofauna along a gradient of intermediate sandy beaches in northern Spain. Estuar. Coast. Shelf Sci. 61:37-44. http://dx.doi.org/10.1016/j.ecss.2004.03.016.

Röper, T., Greskowiak, J., Freund, H., Massmann, G., 2013. Freshwater lens formation below juvenile dunes on a barrier island (Spiekeroog, Northwest Germany). Estuar. Coast. Shelf Sci. 121-122:40-50. http://dx.doi.org/10.1016/j.ecss.2013.02.004.

Röper, T., Kröger, K.F., Meyer, H., Sültenfuss, J., Greskowiak, J., Massmann, G., 2012 Groundwater ages, recharge conditions and hydrochemical evolution of a barrier island freshwater lens (Spiekeroog, Northern Germany). J. Hydrol. 454-455:173-186. http://dx.doi.org/10.1016/j.jhydrol.2012.06.011.

Rotthauwe, J.H., Witzel, K.P., Liesack, W., 1997. The ammonia monooxygenase structural gene amoA as a functional marker: molecular fine-scale analysis of natural ammonia-oxidizing populations. Appl. Environ. Microbiol. 63, 4704-4712.
Roy, M., Martin, J.B., Cherrier, J., Cable, J.E., Smith, C.G., 2010. Influence of sea level rise on iron diagenesis in an east Florida subterranean estuary. Geochim. Cosmochim. Acta 74:5560-5573. http://dx.doi.org/10.1016/j.gca.2010.07.007.

Røy, H., Lee, J.S., Jansen, S., de Beer, D., 2008. Tide-driven deep pore-water flow in intertidal sand flats. Limnol. Oceanogr. 53:1521-1530. http://dx.doi.org/10.4319/lo.2008.53. 4.1521.

Rusch, A., Huettel, M., Wild, C., Reimers, C.E., 2006. Benthic oxygen consumption and organic matter turnover in organic-poor, permeable shelf sands. Aquat. Geochem. 12: 1-19. http://dx.doi.org/10.1007/s10498-005-0784-x.

Santoro, A.E., 2010. Microbial nitrogen cycling at the saltwater-freshwater interface. Hydrogeol. J. 18:187-202. http://dx.doi.org/10.1007/s10040-009-0526-z.

Santos, I.R., Beck, M., Brumsack, H.-J., Maher, D.T., Dittmar, T., Waska, H., Schnetger, B., 2015. Porewater exchange as a driver of carbon dynamics across a terrestrial-marine transect: insights from coupled 222Rn and $\mathrm{pCO}_{2}$ observations in the German Wadden Sea. Mar. Chem. 171:10-20. http://dx.doi.org/10.1016/j.marchem.2015.02.005.

Santos, I.R., Burnett, W.C., Chanton, J., Mwashote, B., Suryaputra, I.G.N.A., Dittmar, T., 2008. Nutrient biogeochemistry in a Gulf of Mexico subterranean estuary and groundwater-derived fluxes to the coastal ocean. Limnol. Oceanogr. 53:705-718. http://dx. doi.org/10.4319/lo.2008.53.2.0705.

Seidel, M., Beck, M., Greskowiak, J., Riedel, T., Waska, H., Suryaputra, I.G.N.A., Schnetger, B. Niggemann, J., Simon, M., Dittmar, T., 2015. Benthic-pelagic coupling of nutrients and dissolved organic matter composition in an intertidal sandy beach. Mar. Chem. 176: 150-163. http://dx.doi.org/10.1016/j.marchem.2015.08.011.

Seidel, M., Beck, M., Riedel, T., Waska, H., Suryaputra, I.G.N.A., Schnetger, B., Niggemann, J. Simon, M., Dittmar, T., 2014. Biogeochemistry of dissolved organic matter in an anoxic intertidal creek bank. Geochim. Cosmochim. Acta 140:418-434. http://dx.doi.org/ 10.1016/j.gca.2014.05.038.

Short, A., Woodroffe, C.D., 2009. The Coast of Australia. Cambridge University Press, New York.

Slomp, C.P., Van Cappellen, P., 2004. Nutrient inputs to the coastal ocean through submarine groundwater discharge: controls and potential impact. J. Hydrol. 295:64-86. http://dx.doi.org/10.1016/j.jhydrol.2004.02.018.

Snyder, M., Taillefert, M., Ruppel, C., 2004. Redox zonation at the saline-influenced boundaries of a permeable surficial aquifer: effects of physical forcing on the biogeochemical cycling of iron and manganese. J. Hydrol. 296:164-178. http://dx.doi.org/10 1016/j.jhydrol.2004.03.019.

Spiteri, C., Slomp, C.P., Charette, M.A., Tuncay, K., Meile, C., 2008a. Flow and nutrient dynamics in a subterranean estuary (Waquoit Bay, MA, USA): field data and reactive transport modeling. Geochim. Cosmochim. Acta 72:3398-3412. http://dx.doi.org/ 10.1016/j.gca.2008.04.027.

Spiteri, C., Slomp, C.P., Tuncay, K., Meile, C., 2008b. Modeling biogeochemical processes in subterranean estuaries: effect of flow dynamics and redox conditions on submarine groundwater discharge of nutrients. Water Resour. Res. 44, W02430. http://dx.doi. org/10.1029/2007WR006071.

Taylor, S.R., McLennan, S.M., 1985. Continental Crust: Its Composition and Evolution. An Examination of the Geochemical Record Preserved in Sedimentary Rocks. Blackwell Scientific, Oxford.

Ullman, W.J., Chang, B., Miller, D.C., Madsen, J.A., 2003. Groundwater mixing, nutrient diagenesis, and discharges across a sandy beachface, Cape Henlopen, Delaware (USA) Estuar. Coast. Shelf Sci. 57:539-552. http://dx.doi.org/10.1016/S02727714(02)00398-0.

Van de Flierdt, T., Pahnke, K., Amakawa, H., Andersson, P., Basak, C., Coles, B., Colin, C. Crocket, K., Frank, M., Frank, N., Goldstein, S.L., Goswami, V., Haley, B.A., Hathorne, E.C., Hemming, S.R., Henderson, G.M., Jeandel, C., Jones, K., Kreissig, K., Lacan, F., Lambelet, M., Martin, E.E., Newkirk, D.R., Obata, H., Pena, L., Piotrowski, A.M., Pradoux, C., Scher, H.D., Schöbert, H., Singh, S.K., Stichel, T., Tazoe, H., Vance, D. Yang, J., 2012. GEOTRACES intercalibration of neodymium isotopes and rare earth element concentrations in seawater and suspended particles. Part 1: reproducibility of results for the international intercomparison. Limnol. Oceanogr. Methods 10 : 234-251. http://dx.doi.org/10.4319/lom.2012.10.234

Vandenbohede, A., Lebbe, L., 2006. Occurrence of salt water above fresh water in dynamic equilibrium in a coastal groundwater flow system near De Panne, Belgium. Hydrogeol. J. 14:462-472. http://dx.doi.org/10.1007/s10040-005-0446-5.

Werner, U., Billerbeck, M., Polerecky, L., Franke, U., Huettel, M., van Beusekom, J.E.E., de Beer, D., 2006. Spatial and temporal patterns of mineralization rates and oxygen distribution in a permeable intertidal sand flat (Sylt, Germany). Limnol. Oceanogr. 51: 2549-2563. http://dx.doi.org/10.4319/lo.2006.51.6.2549.

Wetzel, R.G., Likens, G.E., 2003. Limnological Analyses. Springer-Verlag.

Wilms, R., Sass, H., Köpke, B., Köster, J., Cypionka, H., Engelen, B., 2006. Specific bacterial, archaeal, and eukaryotic communities in tidal-flat sediments along a vertical profile of several meters. Appl. Environ. Microbiol. 72:2756-2764. http://dx.doi.org/10. 1128/AEM.72.4

Wilson, A.M., Gardner, L.R., 2006. Tidally driven groundwater flow and solute exchange in a marsh: numerical simulations. Water Resour. Res. 42:1-9. http://dx.doi.org/10. 1029/2005WR004302

Wong, W.W., Grace, M.R., Cartwright, I., Cook, P.L.M., 2014. Sources and fate of nitrate in a groundwater-fed estuary elucidated using stable isotope ratios of nitrogen and oxygen. Limnol. Oceanogr. 59:1493-1509. http://dx.doi.org/10.4319/lo.2014.59.5.1493.

Xin, P., Robinson, C., Li, L., Barry, D.A., Bakhtyar, R., 2010. Effects of wave forcing on a subterranean estuary. Water Resour. Res. 46, W12505. 